\title{
Thermal and burial history modelling in the Midlothian-Leven Syncline in the Midland Valley of Scotland using BasinMod and HotPot
}

C. J. Vincent ${ }^{1}$, W. J. Rowley ${ }^{1}$ and A. A. Monaghan ${ }^{2}$

${ }^{1}$ British Geological Survey, Kingsley Dunham Centre, Keyworth, Nottingham NG12 5GG

Corresponding author C. J. Vincent cvi@bgs.ac.uk

${ }^{2}$ British Geological Survey, Murchison House, West Mains Road, Edinburgh EH9 3LA

Number of words: $\underline{8618}$

Abbreviated title: Burial history Midlothian-Leven Syncline

Keywords: Midlothian-Leven syncline, Thermal modelling, Burial history, BasinMod, HotPot

\section{Synopsis}

Basin subsidence and thermal history models of the eastern part of the Midland Valley of Scotland have been constructed to characterise the development of the Midlothian-Leven synclinal basin from the mid Mississippian to the present day. Two modelling programs were used: BasinMod and HotPot. BasinMod models are based on thermal maturity at borehole sites; HotPot models operate on stacks of 2D layer grids using a mechanical compaction method. The thermal and burial history modelling indicates up to $1.9 \mathrm{~km}$ of additional burial of Carboniferous strata compared to present day levels: up to $660 \mathrm{~m}$ deposited by the end of the Carboniferous period subsequently removed by Variscan uplift and erosion, followed by up to $1.9 \mathrm{~km}$ of burial 
by sedimentary rocks deposited during the Permian to the Palaeogene periods. Temperatures greater than $130{ }^{\circ} \mathrm{C}$ were reached by the most deeply buried Carboniferous sedimentary rocks. Mississippian (Lower Carboniferous) rocks reached the oil generation window during the mid Carboniferous, with Pennsylvanian (Upper Carboniferous) rocks reaching the oil generation window during the Cretaceous. Sedimentation rates were of $0.03-0.63 \mathrm{~m} \mathrm{ka}^{-1}$ (metres per thousand years) with changes in the rate and the position of depocentres consistent with both extensional and strike-slip basin formation.

The Midland Valley of Scotland (MVS) Terrane has had a prolonged and complex geological history, initiated in the Palaeozoic era as a Caledonide compressional feature but followed by Siluro-Devonian and Carboniferous phases of extensional and strike-slip basin formation (e.g. Smith 1995; Rippon et al. 1996). The post-Palaeozoic history is difficult to define due to erosion and overprinting by younger tectonic events. Carboniferous sedimentary basins exhibit faultbounded and synclinal/anticlinal structural styles typical of extensional to strike-slip settings (Read et al. 2002; Rippon et al. 1996; Ritchie et al. 2003; Underhill et al., 2008). One such Carboniferous basin, the Midlothian-Leven syncline (Figure 1), in the eastern Midland Valley of Scotland, has been extensively studied due to a high quality seismic dataset and coastal exposures. Its tectonic and stratigraphical development is well documented (Ritchie et al. 2003; Underhill et al., 2008) and a schematic model has been proposed for the generation of hydrocarbons which occur around its margins (Underhill et al., 2008). However, detailed numerical data on the burial and thermal history of the basin are lacking. This paper integrates maturity data from three boreholes, compaction data from a further eight boreholes (Table 1) and gridded 2D surfaces of key stratigraphical horizons to investigate the depth, timing and 
temperature of burial of Lower to Upper Carboniferous strata and their subsequent postPalaeozoic history. Much of the thermal maturity data is from Raymond (1991).

The models are constructed using two contrasting modelling packages; Basinmod and Hotpot. BasinMod (Platte River Associates Inc. software) models compaction and temperature through burial over geological time using stratigraphical and vitrinite reflectance maturity data from a borehole. The first step in HotPot (British Geological Survey (BGS) software) is to undertake a depth of burial study using rock density properties of mudstone to map the predicted thickness of eroded overburden within the study area. A calculation is then applied to restore the depositional thickness (backstripping) of stratigraphical units and construct the basin depositional history model. This is in turn used to compute the thermal history model. HotPot provides a basin-wide overview using grids from structural interpretation, giving a 'broad-brush' basin history. BasinMod provides analysis on 1D boreholes and allows detailed variability in sedimentation rates etc., to be considered. The modelling techniques used by HotPot and BasinMod complement each other and were used iteratively to achieve the final model.

\section{Geological setting}

The MVS is bounded by the Caledonide Highland Boundary Fault to the north and the Southern Upland Fault to the south, with an internally complex arrangement of Carboniferous sedimentary basins and Carboniferous volcanic rocks overlying Lower Palaeozoic strata (e.g. Read et al. 2002). The MVS forms part of a system of Late Devonian to Carboniferous sedimentary basins that developed across northern Britain in the foreland of the complex accretion of microplates that made up the Variscan Orogen (e.g. Ziegler 1990). Several different regional tectonic models have been proposed to explain basin formation: back-arc extension in relation to northwards subduction of the Rheic Ocean lithosphere (Leeder 1982); dextral megashear during accretion of Gondwana and Laurentia that stretched from North America to Russia (Arthaud and Matte 1977; Dewey 1982); or dextral escape tectonics of a continental block during the early Carboniferous with sinistral strike-slip movement over the area of the MVS Terrane followed by late 
Carboniferous reversal of the escaping continental block resulting in dextral strike-slip across northern Britain (Coward 1993).

Ritchie et al. (2003) and Underhill et al. (2008) interpreted seismic and onshore data from the Midlothian-Leven syncline and agree that dextral strike-slip determined the formation of NNESSW synclinal basins in the late Carboniferous, followed by end Carboniferous inversion, uplift and magmatism. Interpretations of the early-mid Carboniferous basin development differ. Ritchie et al. (2003) favour extensional NNE-trending half-graben developed under sinistral strike-slip and inverted in the late Carboniferous period following basin-wide subsidence, whereas Underhill et al. (2008) propose syncline formation under dextral strike-slip from the mid to late Viséan stage. This study is partially based upon the 2D stratigraphical layer surfaces from the Ritchie et al. (2003) tectonic and stratigraphical model which fits with the regional tectonic model of Coward (1993).

In this model, active extension in half-graben basins, rapid subsidence and volcanism occurred during Late Devonian to end Mississippian times (Ochil Volcanic to mid Passage Formations; Ritchie et al. 2003). Extension-related magmatism associated with lithospheric thinning and a presumed high heat flow was widespread across the MVS (Smedley 1986; Upton et al. 2004). During the early Pennsylvanian period (mid Namurian), active extension appeared to give way to post-extensional thermal subsidence with local structural inversion and growth folding (Ritchie et al. 2003). Less voluminous extensional, intraplate magmatism continued until Westphalian times (Upton et al. 2004). Mid Pennsylvanian (Westphalian) dextral strike-slip followed the local structural inversion and growth folding (Ritchie et al. 2003). Towards the late Carboniferous climax of the Variscan Orogeny, tightening of the NNE-trending folds and creation of other N- and NW-trending folds occurred resulting in a Westphalian D to Stephanian age unconformity (Corfield et al. 1996; Rippon et al. 1996).

Stephanian to Early Permian post-orogenic extension occurred in response to the gravitational collapse of the Variscan Orogen and far-field dextral extensional stress between Gondwana and 
Laurentian plates (Ziegler 1990; Timmerman 2004). Latest Carboniferous tholeiitic magmatism (Midland Valley Sill complex), including ENE- to ESE-trending tholeiitic dykes and extensional faults, cut across tightened and inverted Carboniferous basins (Rippon et al. 1996; Stephenson et al. 2003). Permian volcanic and sedimentary rocks were subsequently deposited (e.g. Mauchline Basin, Mykura et al. 1967).

\section{Carboniferous stratigraphy}

The interbedded Carboniferous sedimentary and volcanic rocks of the MVS form a succession up to $5 \mathrm{~km}$ thick. The sedimentary rocks were deposited in fluvial, lacustrine and deltaic environments with periodic marine incursions (Browne et al. 1999; Figure 2). Boreholes used in this study penetrate coal measures and Clackmannan Group strata and some sample as deep as the mid Mississippian Strathclyde Group. The latter is divided into vertically and laterally variable formations and is dominantly fluvio-deltaic (Browne et al. 1999; Figure 2). Owens et al. (2005) present an alternative stratigraphical evaluation of Mississippian strata from East Fife based on recent palynological zonations. However, the work presented here is not dependent on which stratigraphical scheme is used. The Upper Mississippian and Pennsylvanian sedimentary rocks of the Lower Limestone to Scottish Middle Coal Measures formations, which form the main units examined in this study, are commonly regionally correlated, cyclical marine to nonmarine deposits with several economically important coal-bearing formations (Browne et al. 1999; Figure 2). A mid-Carboniferous hiatus that affected much of Europe and North America is considered by Read et al. (2002) to occur within the Passage Formation although marine strata were deposited without an erosional surface within the formation during this period so it is difficult to identify the boundary between the Mississippian and Pennsylvanian sub-systems.

\section{Post Carboniferous geological history}

Scotland has been subjected to regional uplift since the early Paleocene (Hillis et al. 1994) due to magmatic underplating from a mantle plume during the opening of the North Atlantic (White 1988). In the MVS, the compaction state of the exposed Carboniferous rocks and the presence of 
late Palaeozoic and Mesozoic successions in parts of Scotland and its offshore waters has led to the hypothesis that the younger successions encroached on the MVS (e.g. Cameron and Stephenson 1985) and have since been removed by uplift and erosion.

There are no proven Permian and Triassic rocks in the Midlothian-Leven synclinal basins but rocks of this age are preserved locally onshore in the Mauchline Basin, Ayrshire (Mykura et al. 1967), on Arran (BGS 1987) and in the Larne Borehole, Northern Ireland (Penn et al. 1983). Sequences of Permian and Jurassic rocks up to c. $1.5 \mathrm{~km}$ thick are preserved offshore in the outer Firth of Forth/Forth Approaches and in the Firth of Clyde (BGS 1985; Cartwright et al. 2001). North of the MVS, Jurassic to early Cretaceous sedimentary rocks crop out in the Inner Moray Firth (Hillis et al. 1994). Gatliff et al. (1994) describe the Jurassic to Cretaceous rocks found in the central North Sea, adjacent to the Midland Valley Terrane. Jurassic and Cretaceous rocks are also found in vent masses in Arran (BGS 1987), supporting the view of published palaeogeographies (e.g. Coward et al. 2003) that warm seas covered the MVS during the Late Cretaceous period. In summary, late Palaeozoic and Mesozoic deposition may have been substantial across the MVS. Sedimentary deposition is likely to have ended at around $60 \mathrm{Ma}$, during the early Palaeogene, coeval with the start of North Atlantic magmatism, uplift and erosion.

\section{Summary of the BasinMod model}

BasinMod (Platte River software) is designed to model the basin geo-history and thermal maturity through time. Calculations are based on individual modelled stratigraphic units to allow accurate decompaction and backstripping. Thickness of units in boreholes, average lithologies and other rock parameters are entered for each stratigraphical unit and an appropriate method for decompaction is selected by the user. Palaeo-thermal history is reconstructed from measured data such as vitrinite reflectance. 


\section{Selection of boreholes}

Data were entered into the BasinMod (version 7 and 3.1, Platte River Associates Inc.). Boreholes were selected on the following criteria: length of bore, suitable stratigraphical detail and availability of vitrinite reflectance (VR) data. A large number of boreholes were considered for modelling, but vitrinite reflectance data were rarely available in sufficient quantity to reliably calibrate the model, thus the number of suitable boreholes was limited. The three chosen boreholes were Firth of Forth Tower 1 and Milton of Balgonie boreholes on the western limb of the Leven Syncline and Eskmouth Borehole close to the Midlothian syncline axis (Figure 1). VR data for the Eskmouth and Milton of Balgonie boreholes were taken from Raymond (1991).

\section{Maturity modelling using BasinMod}

Borehole stratigraphy and rock properties were used to model compaction and temperature through burial over geological time in the three boreholes. Eroded overburden was modelled based on surrounding boreholes and literary sources such as Cameron and Stephenson (1985). The modelled maturity and measured maturity data were then compared graphically and used to iteratively develop the model until a good fit to the VR data was achieved (see below for description of influence that heat flow and overburden have on the modelled VR curve). The slope of the modelled maturity (VR) plot is influenced by the palaeo-heat flow, the maturity at any particular time is more strongly influenced by the thickness of overlying sediments.

BasinMod 1D calculates heat flow curves based on the finite rifting model of Jarvis and McKenzie (1980). This assumes that in an extensional environment there is rapid initial subsidence due to crustal thinning associated with a thermal anomaly, i.e. high heat flow. This model recognises that continental basin formation by extension takes a finite time. When crustal stretching ceases, heat is lost by vertical conduction and the slow decay of the heat flow leads to further subsidence due to thermal contraction. For modelling heat flow in basins with limited extension (stretching factor $\beta$, which measures the thickness of the crust at a given time relative 
to its initial thickness, where a value greater than 1 indicates the crust has been extended and thinned), the Jarvis and McKenzie (1980) model plots thermal anomaly development and decay based on typical heat conduction properties of lithologies. The heat flow curves for this paper were based on the Jarvis and McKenzie model with minor modifications (e.g. slowing decay of heat flow in the late Carboniferous to influence the steepness of model VR curve) to better fit the data, and also to accommodate the geological history of underplating of the region. The palaeoheatflow curve used for modelling was based on the assumption that extension would have been associated with high heat flow from the start to the end of the Mississippian (early Namurian) sub-period. High heat flow was expected to continue with active faulting and folding into the early Pennsylvanian (mid-Namurian) sub-period as extension continued. During mid-Namurian times, active rifting is inferred to have given way to post-extensional thermal subsidence. The heat flow would be expected to slowly decline after active rifting and volcanism had ceased. As the youngest strata in the boreholes is of Carboniferous age, more detailed modelling of the heat flow using BasinMod after this time was not attempted and thus it was assumed that the heat flow declined slowly to the present day level based on the Jarvis and McKenzie (1980) model. The current heat flow in Edinburgh is around $53 \mathrm{~mW} \mathrm{~m}^{-2}$ (milli Watts per square metre) (Rollin et al. 2002). Average surface temperatures were added for completeness to the BasinMod and HotPot models. It was assumed surface temperatures were generally higher during the Carboniferous period when this region was near the equator, and then slowly declined to the present day average of around $9{ }^{\circ} \mathrm{C}$ (Meteorological Office 2004). For simplicity of the model, it was assumed that any additional Carboniferous strata deposited before the Variscan that is not seen in the present day stratigraphy was removed by the uplift and erosion associated with the Variscan tectonic event and Permian sediments were deposited unconformably on this erosional surface. A second period of non-deposition/erosion, beginning around 60Ma during the early Palaeogene, at the start of North Atlantic magmatism, uplift and erosion, was also included in the BasinMod models. 
For modelling purposes, lithology mixes were constructed based on the selected boreholes. Eroded overlying lithologies of Carboniferous to Present age were approximated using borehole records held by BGS Keyworth National Geoscience Records Centre and Murchison House, Edinburgh and available literature cited elsewhere in this paper. Overlying depth of water was not included in the BasinMod models because it has a relatively minor influence on the model calculations for the deeply buried Carboniferous formations.

Plots of the modelled maturity and temperature vs. depth and time from the boreholes modelled with BasinMod were produced (Figures 3 to 5). These model results were then compared with the HotPot results at those sites and used to iteratively improve both the BasinMod and HotPot models.

\section{Eskmouth Borehole}

Eskmouth Borehole 50/56 (Reference NT37SW/31, British National Grid reference [334530 673320]) lies on the axis of the Leven Syncline south of the HotPot modelling area. The borehole has a good distribution of vitrinite reflectance data (Raymond 1991). The borehole stratigraphy was entered into the BasinMod model divided on the basis of formation, then further subdivided based on rock characteristics to refine the model. The BasinMod burial history and model isotherms $\left(10^{\circ} \mathrm{C}\right.$ spacing) are shown in Figure 3. Not all stratigraphical layers used in the model are shown on the diagram for clarity. The horizontal line across the top of the model indicates the present day 'surface' and model layers intersected by this line have been eroded before the present day. Comparison of the vitrinite reflectance data with the modelled maturity and the modelled heat flow are illustrated in Figures 3b and 3c. Some scatter of the vitrinite reflectance (VR) data may be a result of 'suppression' due to the presence of algal matter (Carr 2000). The Eskmouth Borehole can be successfully modelled using a maximum heat flow of around $67 \mathrm{~mW} \mathrm{~m}^{-2}$ during mid-Carboniferous times and deposition of an additional $450 \mathrm{~m}$ (uncompacted thickness) of strata during the late Pennsylvanian period. It was assumed these additional strata were eroded during Variscan tectonic activity (at the end of Pennsylvanian 
period, around 300 My before present day). A further $1800 \mathrm{~m}$ of sediment deposition was added to the model for Permian to Paleocene strata. The eroded thicknesses were modelled based on the best fit of the modelled maturity to the VR data. This model predicts a maximum depth of burial of $2900 \mathrm{~m}$ for the top of the Lower Limestone Formation during the Cainozoic period when the maximum temperature of $115^{\circ} \mathrm{C}$ was reached. The model results for the Eskmouth Borehole in Figure 3b imply the Lower Limestone and Limestone Coal formations reached the oil generation window during the mid to late Carboniferous, and that the younger strata up to the mid Upper Coal Measures Formation reached the oil window during maximum burial in the Palaeogene period.

The Eskmouth Borehole stratigraphy was used to calculate approximate sedimentation rates for major formations. The Passage Formation has a relatively low sedimentation rate of around $0.03 \mathrm{~m} \mathrm{ka}^{-1}$ (metres per thousand years) based on the borehole stratigraphy. The Upper Limestone Formation has a sedimentation rate of approximately $0.13 \mathrm{~m} \mathrm{ka}^{-1}$ and the Limestone Coal Formation a rate of approximately $0.19 \mathrm{~m} \mathrm{ka}^{-1}$. The Scottish Lower Coal Measures Formation have a sedimentation rate of approximately $0.10 \mathrm{~m} \mathrm{ka}^{-1}$.

\section{Tower 1 Borehole}

Firth of Forth Tower 1 Borehole (Reference NT38NW/1, British National Grid Reference [330024 687894]) lies on the west limb of the Leven Syncline (Figure 1). There is not as abundant nor such a good coverage of VR data in comparison to Eskmouth Borehole, so the heat flow used for this model was largely based on the heat flow used for Eskmouth (Raymond 1991). A thin sill intrudes through this borehole, but does not appear to have affected the available vitrinite reflectance data (Figure 4a). The data from Tower 1 Borehole can be successfully modelled using a maximum heat flow of around $82 \mathrm{~mW} \mathrm{~m}^{-2}$ in the Carboniferous and deposition of an additional $420 \mathrm{~m}$ of sediment at the end of the Carboniferous (which was then assumed to have been removed by erosion by Variscan tectonic events) and 1900 m sediment deposition through the Permian to Palaeogene (Figure 4a). This model predicts a maximum depth of burial 
of $2900 \mathrm{~m}$ for the Limestone Coal Formation during the Cainozoic period when the maximum temperature of around $110{ }^{\circ} \mathrm{C}$ was reached. Figure 4a suggests that the Limestone Coal Formation in Tower 1 Borehole entered the oil window at shallower depth than in the Eskmouth Borehole during the Carboniferous Period and the younger strata up to the Lower Coal Measures reached the oil generation window during deep burial in the Early Palaeogene. Strata thickness changes for the Palaeogene are based on geological interpretation as the BasinMod models are less constrained due to the lack of VR data. This is consistent with the borehole location being on the basin margin. The heat flow (Figure 4c) was modelled as being similar to Eskmouth Borehole.

The sedimentation rates were again calculated from the borehole stratigraphy using BasinMod. The Passage Formation again appears to have a relatively low sedimentation rate of $0.07 \mathrm{~m} \mathrm{ka}^{-1}$. The Upper Limestone Formation has a sedimentation rate of approximately $0.15 \mathrm{~m} \mathrm{ka}^{-1}$ and the Limestone Coal Formation a rate of approximately $0.16 \mathrm{~m} \mathrm{ka}^{-1}$ (though this sedimentation rate estimation may have been affected by intrusion of an 18-m thick sill in this layer).

\section{Milton of Balgonie Borehole}

Milton of Balgonie Borehole is located in the north of the study region near an anticlinal high on the margins of the Leven Syncline (Figure 1) (Reference NT39NW/385, British National Grid Reference [331733 699335]). This borehole cuts through the Midland Valley Sill complex (Figure 5a), which caused localised heating of the strata in the Lower Limestone Formation (Raymond 1991). Figure 5b clearly shows the effects of igneous intrusion; the vitrinite reflectance data show a sharp peak around the sill indicating localised heating. The few points of vitrinite reflectance data in the Strathclyde Group that are considerably higher than the clustered trend are also located near minor intrusions.

The data from Milton of Balgonie Borehole can be successfully modelled using a maximum heat flow of around $68 \mathrm{~mW} \mathrm{~m}^{-2}$ (Figure 5c) during the Carboniferous period. Deposition of an additional $660 \mathrm{~m}$ of sediment (which was then assumed to have been removed by erosion during 
the Variscan Orogeny) at the end of the Carboniferous period was modelled and a further 1300 m sediment deposited through the Permian to Palaeogene periods. This model predicts a maximum depth of burial of $2300 \mathrm{~m}$ for the Limestone Coal Formation when the maximum temperature of around $95{ }^{\circ} \mathrm{C}$ was reached. The high VR values resulting from the igneous intrusions were not considered in the model VR curve since the interest here was in the compaction and burial of the sedimentary rocks in this region. However, the intrusion of the Midland Valley Sill and other intrusions may have affected the sedimentation rate estimations. BasinMod results indicate that the Strathclyde Group strata reached the oil generation window during the Late Mississippian to Pennsylvanian and the younger strata up to the Limestone Coal Formation entered the oil window during Cainozoic burial.

The sedimentation rates were calculated in BasinMod using Milton of Balgonie Borehole stratigraphy. The Passage Formation again appears to have a relatively low sedimentation rate of $0.05 \mathrm{~m} \mathrm{ka}^{-1}$. The Upper Limestone Formation has a sedimentation rate of $0.14 \mathrm{~m} \mathrm{ka}^{-1}$, the Limestone Coal Formation a rate of $0.19 \mathrm{~m} \mathrm{ka}^{-1}$ and the Lower Limestone Formation a rate of $0.22 \mathrm{~m} \mathrm{ka}^{-1}$ (though this value may have been affected by intrusion of the Midland Valley Sill). The Strathclyde Group underneath this reaches a thickness of $805.7 \mathrm{~m}$ and the Pittenweem beds are identified at $1798 \mathrm{~m}$ BRT (below rotary table). Using the age of this bed from the borehole $\log$ and the thickness of sediment, BasinMod gives a sedimentation rate of approximately $0.13 \mathrm{~m}$ $\mathrm{ka}^{-1}$.

\section{Summary of the HotPot model}

The BGS modelling program HotPot (Rowley et al. 1993) produces pseudo-3D depositional and thermal history models of sedimentary basins using a surface-based approach. This is the counterpoint to standard commercial oil-industry basin modelling software, such as BasinMod, which use vertical modelling methods, either at well-bores (1D) or along cross-sections (2D). In HotPot modelling, the basin fill is first backstripped, that is starting with the most recent layer and successively stripping away one layer at a time, restoring by decompaction the thicknesses 
of the underlying strata. Then a vertical heat transfer calculation is applied at each stage of the reconstructed depositional history, to synthesise the thermal history of the basin fill. Where the topmost preserved layer is not a recent deposit, it is necessary to estimate the thickness of eroded overburden and introduce it as a layer to be restored during modelling.

\section{Depth of burial study}

The youngest strata preserved in the study area are of late Carboniferous Bolsovian (Westphalian C) age (BGS 1999). As discussed previously, the original succession probably included Permian and younger strata which have been eroded, thus a depth of burial study was carried out to estimate the thickness of these eroded strata.

As sedimentary deposits are progressively buried, their porosity decreases and their density increases. This relationship has been demonstrated by laboratory and theoretical work (Sclater and Christie 1980; Baldwin and Butler 1985) and observed in borehole logs (e.g. Lang 1980). Compaction also depends on sediment type; for example, mudstones compact more readily and to a greater degree than sandstones. The compaction process is irreversible; sediments do not 'decompact' if their burial depth is reduced by uplift and erosion. Once a set of compaction curves (density vs. depth vs. lithology, Figure 6) have been established from a fully preserved sequence, the maximum depth to which a sample, of known lithology and density, was buried is determined by finding the density on the appropriate curve and reading the corresponding depth. An estimate of the thickness of overburden eroded from the sample site is then obtained by subtracting the present depth of the sample from its maximum burial depth (Figure 6).

The present day stratigraphical succession in the Firth of Forth basin is not at maximum depth of burial (Figure 6) and is incomplete, thus phases of deposition, uplift and erosion during the Mesozoic and Cainozoic periods are inferred. Therefore, the adopted compaction curves were derived from data used in earlier studies of the Cheshire Basin (Chadwick et al. 1999) and the Wessex Basin (Chadwick 1985), supplemented by theoretical data. 
The reliability of this method depends on the observed sample densities being due solely to sediment compaction. However, other factors may alter the density of sedimentary rocks, such as recrystallisation of limestones or changes in the cementation of sandstones. Previous studies (e.g. Marie 1975; Magara 1976) indicate that the best depths of burial estimates are obtained from mudstones.

Eight boreholes with a reasonable depth of penetration and density logs were selected from the available borehole data in the study area (Table 1 and Figure 1). For each borehole, the gammaray $\log$ was used to define a shale-line and so indicate mudstone-dominated intervals. Such intervals were rejected if the calliper log indicated significant amounts of caving. The shale-line, as calculated from the gamma log, was compared to the lithological 'picks' by the site geologist or CORIBAND log (calculated lithological log), where available, and found to be in broad agreement.

Modern density logs were compensated for borehole diameter effects by the logging service providers, but older logs required manual compensation, a possible source of error as the compensation charts are plotted on a logarithmic scale and it is difficult to estimate accurate values. Log calibration is also a significant source of uncertainty; density logs are relative-value tools and scaling in terms of absolute density values requires careful calibration. Different tools and calibration sources can yield significantly different results.

The density vs. depth data were plotted against, and compared to, the standard compaction curves for mudstone and mudstone with $10 \%$ sandstone. The thickness of eroded overburden could then be estimated from the vertical offset of the borehole data from the standard curve (Figure 6). Table 1 summarises the results of the depth of burial study, showing the maximum depth of burial and thickness of eroded overburden at each of the selected borehole locations.

A common procedure for assessing the reliability of overburden estimates is to add them to the observed depths for a basin-wide stratigraphical horizon. If this produces a smooth surface, then the overburden estimate can be considered consistent. However, in this case, the data were not 
suitably evenly distributed and so a qualitative assessment was made as part of the overburden mapping. A contour map of the estimated overburden was produced using the values in Table 1 and taking into account the overall structural trends of the Midlothian-Leven syncline. These contours were then digitised and gridded (Figure 7).

Each BasinMod borehole model included apportioned thicknesses of sediment deposited and removed during inferred post-Carboniferous phases of subsidence, uplift and erosion. However, there is insufficient evidence to realistically extend such apportionment to the overburden mapped in the depth of burial study. A single layer was therefore used in the HotPot model to represent all deposition from end Carboniferous until about 60 Ma before present and its subsequent erosion. The lithological composition of the overburden (Table 2) was estimated from preserved Mesozoic and Cainozoic strata in basins in England and the North Sea.

\section{HotPot burial history modelling}

\section{Input data}

The areal extent of the HotPot model is shown in Figure 1, and the spatial resolution of the model grid was $1 \mathrm{~km}$. These parameters and depth data were obtained from the mapping of structural evolution in the Firth of Forth presented by Ritchie et al. (2003).

The stratigraphical table for the model (Table 3 and Figure 2) illustrates the main stratigraphical units for the Firth of Forth basin and the grouping of the formations for HotPot basin modelling. The Hotpot layer parameters by stratigraphical unit are given in Table 2.

\section{Burial history modelling results}

The results of backstripping the present day stratigraphy are shown in Figure 8. The eroded overburden layer is represented by an unconformity marker at the top of the 0.5 Ma column and is reconstructed as a deposited layer at the top of the 60 Ma column. 
Thickness maps of backstripped and decompacted strata are shown in Figure 9 to illustrate stages in the development of the basin. The maps use a common contour scale for ease of comparison. The Limestone Coal to Passage formations model layer (Figure 9a) is the lowest unit interpreted over the whole area so this was used to illustrate the development of the basin from 316 Ma to 60 Ma before present when the maximum depth of burial was attained. Data quality was poorer for the deeper horizons, which may have introduced artefacts into the grids during the original structural modelling; such artefacts tend to be exaggerated by the decompaction computation.

Nevertheless, the pattern observed is sufficiently distinct to suggest that the development of the basin conforms to a two-stage scenario, with initial rapid subsidence in small, discrete sub-basins (Figures 9a and 9b), followed by slower, broad, basin-wide subsidence (Figures 9c and 9d). This is typical of an extensional or divergent margin setting but could be compatible with a strike-slip setting (Miall 1999, chapter 9; Allen and Allen 1990, chapters 3, 5 and 7). Figure 9a illustrates the initial subsidence phase, with sub-basins apparent in the central and eastern part of the area during deposition of the Kinnesswood, Lower Limestone, Limestone Coal and Passage formations. The transition to a thermal relaxation type subsidence began as the Scottish Middle Coal Measures Formation was deposited (Figure 9b), with a blanket of sediment starting to form a single depocentre. This continued through the accumulation of the Upper Coal Measures (Figure 9c) and was projected until the maximum depth of burial was reached at $60 \mathrm{Ma}$ (Figure 9d).

Burial history plots were extracted from the stacked HotPot grids. Figure 10 shows a burial history plot near the basin depocentre. Other burial history plots were extracted for comparison with the BasinMod plots.

Rates of deposition were estimated for the Carboniferous strata (Table 4) for the decompacted HotPot layers. 


\section{HotPot thermal modelling}

The second, thermal history modelling stage of HotPot uses a method of $1 \mathrm{D}$ vertical heat transfer, which is applied successively to each stack of grid nodes to compute the temperature distribution at the base of each layer at each stage of the depositional history.

\section{Additional input data}

The thermal conductivity of sedimentary rocks is dependent on lithology, and increases with depth and temperature up to around $300{ }^{\circ} \mathrm{C}$, after which the change becomes negligible. A set of thermal conductivity vs. depth vs. lithology curves, derived from the observed, near-complete Mesozoic to Neogene sequence in Denmark (Balling et al. 1981), and used in an earlier study of the Cheshire Basin (Chadwick et al. 1999), has been adopted here.

Heatflow measurements have been made in the Firth of Forth basin area. However, these observations are too sparsely distributed to produce a reliable heatflow map of the area and so the value of $53 \mathrm{~mW} \mathrm{~m}^{-2}$ for the present day heat flow at Edinburgh (Rollin et al. 2002) has been adopted basinwide for this modelling. As the Firth of Forth basin is small, and heatflow variation in the SE of Scotland is gradual, this is believed to be valid.

Estimating the palaeo-heatflow is problematic. The assumptions were that the late Palaeozoic basin development took place in a dominantly extensional regime, that the basin was largely unaffected by Mesozoic extension (which formed basins to east and west of Scotland but seems to have left the mainland as a high) and that there was some heat input during the Cainozoic igneous episode. The validity of these assumptions in the light of modelling results is discussed below. The sediment-starved (tectonic) basin subsidence values obtained from the HotPot burial history modelling indicate initial subsidence was in the range $1200-1400 \mathrm{~m}$ in the central part of the basin. When the basin reached maximum depth of burial, the tectonic subsidence reached about $2100 \mathrm{~m}$. These subsidence rates would be consistent with a McKenzie (1978) extensional model having stretching factor $\beta \approx 1.5$, which has been adopted here for construction of the basic 
heatflow vs. time profile. An instantaneous extension at 360 Ma before present was assumed at the start of the curve. A local heatflow pulse incorporated at $60 \mathrm{Ma}$ before present represents heat input due to Cainozoic igneous activity. The baseline of the curve has been shifted to yield the observed present day heatflow of $53 \mathrm{~mW} \mathrm{~m}^{-2}$. The heatflow vs. time profile constructed is shown in Figure 11.

The present day average annual surface temperature of the Firth of Forth area is approximately $9{ }^{\circ} \mathrm{C}$ (Meteorological Office, 2004). This has also been assumed as the likely average surface temperature 0.5 Ma before present when deposition of the superficial deposits began. From late Palaeozoic through the Mesozoic to early Cainozoic times Britain migrated progressively northwards from equatorial latitudes due to continental drift (Trewin and Rollin, 2002) and was much warmer than at the present day. Thus, a constant value of $20^{\circ} \mathrm{C}$ has been adopted for surface temperatures from 60 Ma to 355 Ma before present.

\section{Thermal results}

A selection of the temperature maps produced from the modelling is shown in Figure 12. These illustrate the increase in temperature at the base of the Limestone Coal to Passage formations stratigraphical unit from immediately after its deposition (316 Ma before present) until maximum burial (60 Ma before present). Comparison with the corresponding sediment thickness maps (Figure 9) shows a broad agreement of temperature with total sediment thickness. Local differences are due to variations in thermal conductivity with the infill of the sub-basins (seen especially in the 316 and 314 Ma maps, Figures 9a, b and 12a, b).

Thermal history plots were extracted from the stacked HotPot grids at three grid nodes closest to the sites used in the BasinMod modelling and compared to the BasinMod results.

The burial and thermal histories may be combined to estimate likely geothermal gradients. Table 5 shows some estimates made for a series of grid nodes around the centre of the basin and at maximum burial, 60 Ma before present. The total thickness was obtained from the sediment- 
loaded thickness grid and the temperatures are for strata at the base of the Lower Carboniferous sequence. From these, it is estimated that the likely geothermal gradient 60 Ma ago was about $24.5^{\circ} \mathrm{C}$ per kilometre.

\section{Comparison of the BasinMod and HotPot results}

A limitation of the decompaction method of depth of burial analysis used with HotPot is that it cannot detect overprinting. Where preserved strata have been subject to a sequence of events that includes more than one phase of deposition followed by uplift and erosion, this method can predict the maximum depth of burial but not during which period of burial it occurred. Neither can it determine burial that occurred before overprinting. Thus in the Firth of Forth basin, all it can predict is one apparent episode of deposition, stretching from Carboniferous to early Cainozoic, followed by the uplift and erosion at 60 Ma before present.

Thermal calibration as used by BasinMod software allows modelling of the burial and heating that occurred prior to Variscan uplift during latest Pennsylvanian. This was an important episode in the thermal history of the preserved strata, because the regional heatflow was probably then almost at its highest, so any significant burial would have resulted in marked heating and maturation of organic matter. Conversely, in the HotPot model, this episode is effectively ignored leading to a possible underestimate of maturity and an estimation of much later timing for thermal events.

The BasinMod results could be used to introduce the 'missing' phase of pre-Variscan deposition and erosion into the HotPot model. However, this would require much more extensive work with BasinMod, to construct models at a similar number of sites to the eight used in the HotPot depth of burial study, so that an isopach map could be constructed to represent the layer of eroded late Carboniferous strata. 
A comparison of the maximum burial depths and temperatures obtained from BasinMod and HotPot modelling at the borehole sites used with BasinMod is presented in Table 6. HotPot temperatures and depths of burial are at base of Passage to Limestone Coal formations model layer at 60 Ma before present in the period of maximum burial during the Cainozoic. BasinMod temperatures and depths of burial are at the base of Limestone Coal Formation during maximum burial in the Cainozoic, except for in Tower 1 Borehole where the top of the underlying Lower Limestone Formation is not sampled.

In comparison to the HotPot results given above, at the base of the Limestone Coal Formation, the BasinMod models predict that during maximum burial (during the Cainozoic) the temperature at the site of the Milton of Balgonie Borehole is about $95{ }^{\circ} \mathrm{C}$ with a maximum depth of burial $2300 \mathrm{~m}$. The base of the Limestone Coal Formation is not seen in the Tower 1 Borehole, though around $227 \mathrm{~m}$ of Limestone Coal strata are observed compared to $244.8 \mathrm{~m}$ in the Milton of Balgonie Borehole and $216.9 \mathrm{~m}$ in the Eskmouth Borehole. The thickness of the Limestone Coal Formation in this area is expected to be around 100-250 m (Cameron and Stephenson 1985). On the basis of formation thickness in the other boreholes and expected thickness based on mapping of this formation, it was assumed that most of the formation was recovered in the Tower 1 Borehole and the maximum depth of burial (2900 m) and temperature $\left(110^{\circ} \mathrm{C}\right)$ of the lowest strata observed in the borehole are likely to be similar to that which would be shown by the model if the borehole had reached the base of the Limestone Coal Formation. . The BasinMod model of the Eskmouth Borehole shows a maximum depth of burial of $2900 \mathrm{~m}$ and a maximum temperature of $115{ }^{\circ} \mathrm{C}$ at the base of the Limestone Coal Formation. The BasinMod and HotPot results at the site of Tower 1 Borehole and Milton of Balgonie Borehole are comparable.

Interpretation of modelling results

Miall (1999) gives a list of the properties usually associated with back-arc basins: deep marine sediment-fill; transition into slope and shelf facies on the continental margin of the basin; little 
evidence of contemporaneous tectonics except normal faulting. Miall (1999) also gives a list of properties usually associated with basins generated by transcurrent faulting; most basins are only a few tens of kilometres across; strata are characterised by numerous local facies changes; movement on individual faults may be local and spasmodic, so that sediments in adjacent basins may have different stratigraphy; syndepositional features; the basin may be cut by later transcurrent faults; sedimentation rates are rapid, commonly exceeding $1 \mathrm{~m} \mathrm{ka}^{-1}$.

The sedimentation rates of the Carboniferous strata for the BasinMod models are around $0.1 \mathrm{~m} \mathrm{ka}^{-1}$. Sedimentation rates computed from the HotPot model for this period show sedimentation rates rising from $0.2 \mathrm{~m} \mathrm{ka}^{-1}$ to $0.6 \mathrm{~m} \mathrm{ka}^{-1}$ (Table 4). The ranges of the sedimentation rate estimations from the two modelling procedures broadly agree, but are lower than the indicative sedimentation rate given by Miall (1999) for pull-apart basins. Sedimentation rate for the Strathclyde Group from BasinMod is estimated at $0.13 \mathrm{~m} \mathrm{ka}^{-1}$ in Milton of Balgonie Borehole and $0.11 \mathrm{~m} \mathrm{ka}^{-1}$ for the HotPot Lower Carboniferous layer. This ties in with early Carboniferous active extension, rapid basin subsidence and volcanism (Ritchie et al. 2003).

From the BasinMod sedimentation rate estimates, the Passage Formation (late Namurian to early Westphalian in age) generally appears to have a low sedimentation rate varying from 0.03-0.07 $\mathrm{m} \mathrm{ka}^{-1}$ for Tower 1 and Eskmouth boreholes. It is laterally variable in composition and thickness and contains local unconformities related to tectonic instability (Read et al. 2002), possibly linked to the reversal of movement on continental blocks associated with the closure of the Ural Ocean (Coward 1993). The Passage Formation also includes the widespread, possibly eustatic Mid-Carboniferous hiatus, so a low overall sedimentation rate probably reflects the presence of unconformities within the Passage Formation.

The Upper Limestone and Limestone Coal formations (Namurian) deposited prior to the Passage Formation have a higher sedimentation rate in the BasinMod models of 0.13-0.19 $\mathrm{m} \mathrm{ka}^{-1}$. The Passage to Limestone Coal formations HotPot model layer has a sedimentation rate of 0.18 $\mathrm{m} \mathrm{ka}^{-1}$. The Westphalian HotPot layers show a high sedimentation rate estimate of 0.45-0.63 m 
$\mathrm{ka}^{-1}$. The BasinMod sedimentation rate estimate is lower at $0.1 \mathrm{~m} \mathrm{ka}^{-1}$ for the Scottish Lower Coal Measures Formation in Eskmouth Borehole, south of the HotPot grid area and away from the main depocentre. These sedimentary rocks were deposited during the post-extensional basinwide thermal subsidence phase with localized inversion and growth folding (Ritchie et al. 2003). As such, the relatively high sedimentation rates may reflect the growth folding visible on seismic data of the Leven Syncline, linked to dextral strike-slip (Ritchie et al. 2003). Overall, the HotPot model shows strong evidence of extensional style initial synrift deposition in sub-basins followed by broad basin-wide thermal sag subsidence (Figure 9). Taking both the variability in sedimentation rates and the HotPot depositional model, the authors conclude that basin formation included both extensional and strike-slip components. However, it is difficult to conclude which process was dominant.

\section{Thermal maturation and the oil window}

Small quantities of oil and natural gas have been produced from Carboniferous rocks in the SE Midland Valley (Hallett et al. 1985). Along with proven occurrences in exploration wells, the hydrocarbons are trapped in anticlinal highs adjacent to the Midlothian-Leven syncline and sourced from the West Lothian Oil Shale Formation (Strathclyde Group) ( Figure 2; Underhill et al. 2008). Underhill et al. (2008) proposed both Carboniferous and Mesozoic maturation in the oil generation window for Lower Carboniferous source rocks in their schematic burial history curve. The data-based modelling presented here supports and expands that view.

The BasinMod results imply that in the Eskmouth Borehole, the rocks of the Limestone Coal Formation and Lower Limestone Formation reached the oil window from the mid-Carboniferous onwards (Figure 4b) and that eventually all the strata up to and including the Scottish Upper Coal Measures Formation entered the oil window during mid-Cretaceous burial. Tower 1 Borehole shows the mid-maturity oil window being reached at a greater depth than in Eskmouth Borehole by the Limestone Coal and Upper Limestone formations during the Permian, with the Scottish Lower Coal Measures Formation reaching the oil window during Palaeogene deep 
burial (Figure 5b). Strata in the Milton of Balgonie Borehole show some of the greatest maturity values. Here the Strathclyde Group reached the oil window during the mid-Carboniferous and the Lower Limestone Formation towards the end of the Carboniferous. The Limestone Coal Formation also appears to have reached the oil window during Cainozoic deep burial (Figure 5a). Some extremely high maturities are shown by the vitrinite reflectance localised around the Midland Valley Sill (Figure 5b). These have been discussed in more detailed by Raymond and Murchison (1988).

Unlike BasinMod, HotPot does not perform organic maturity modelling. However, maturity estimates may be obtained from HotPot models by displaying the temperature maps with a pseudo-maturity scale, which distinguishes areas where strata reached under-mature (lower than $\left.100{ }^{\circ} \mathrm{C}\right)$, oil maturation $\left(100-150{ }^{\circ} \mathrm{C}\right)$, gas maturation $\left(150-220^{\circ} \mathrm{C}\right)$ and over mature (higher than $220^{\circ} \mathrm{C}$ ) burial temperatures. These maps are useful in indicating the likely extents of these zones at the various stages in a basin's development.

The HotPot pseudo-maturity maps indicate that the Lower Carboniferous strata entered the oil window after $327 \mathrm{Ma}$ before present (base Namurian), by $316 \mathrm{Ma}$ before present (base Westphalian) about 50\% of the mapped subcrop area was warm enough for oil generation to occur, and by 311 Ma before present (oldest Westphalian C; Bolsovian) all but a strip on the eastern edge of the subcrop was capable of generating oil. The Passage to Limestone Coal formations entered the oil window in the period between 314 and 311 Ma before present (early Pennsylvanian; Westphalian B Duckmantian), by the end of which about a quarter of the extent of the Carboniferous sequence was in the area above the $100{ }^{\circ} \mathrm{C}$ isotherm (Figure 13). The higher Carboniferous strata had not entered the oil window by 311 Ma before present. The next time reference in the HotPot model is $60 \mathrm{Ma}$ before present (Figure 8), when maximum burial was reached, and the entire Kinnesswood to Lower Limestone formations stratigraphical unit was within the oil window, as was almost half the Passage to Limestone Coal formations stratigraphical unit. However, the HotPot model indicates that at this time only a small area 
around the depocentre of the Scottish Lower to Middle Measures formations reached maturity, with higher strata remaining under-mature.

BasinMod calculates maturity based on temperature and pressure. The burial history diagrams indicate that early maturity and oil generation is anticipated at lower temperatures for this modelling package compared to those used for determining the maturity for the HotPot models. Lowest Carboniferous strata are only present in the BasinMod model of Milton of Balgonie, this shows the Strathclyde Group reaching $100{ }^{\circ} \mathrm{C}$ around 327 Ma before present, which agrees with the HotPot results. Eskmouth and Tower 1 boreholes do not sample the early Carboniferous strata. However, the heat flow in these areas is modelled as higher than in Milton of Balgonie Borehole as the Limestone Coal Formation and Lower Limestone Formation appear to reach 100 ${ }^{\circ} \mathrm{C}$ during Jurassic deep burial, whereas in Milton of Balgonie Borehole, these formations do not reach $100{ }^{\circ} \mathrm{C}$ except for close to the sill. HotPot predicted that the Limestone Coal to Passage formations would reach $100{ }^{\circ} \mathrm{C}$ earlier than predicted by BasinMod (300 Ma before present in the Eskmouth Borehole or 182 Ma before present in Tower 1 Borehole). BasinMod and Hotpot both show the highest temperatures and greatest maturity during deep Palaeogene burial (with the exception of strata close to igneous intrusions).

\section{Discussion}

BasinMod was used successfully to model three boreholes in the MVS using 420-660 m preVariscan additional deposition followed by Variscan erosion and then 1300-1800 m Permian to Palaeogene strata deposition followed by recent erosion. The selected boreholes could be successfully modelled with the following strata thicknesses: Eskmouth Borehole using $450 \mathrm{~m}$ deposited before the Variscan Orogeny, and then a further $1800 \mathrm{~m}$ deposited during the Permian

to the Palaeogene periods subsequently eroded before present day; Firth of Forth Tower 1 Borehole with 420 m deposited before the Variscan Orogeny and 1750 m during the Permian to the Palaeogene periods subsequently eroded before present day; Milton of Balgonie Borehole 
with $660 \mathrm{~m}$ deposited before the Variscan Orogeny and $1300 \mathrm{~m}$ during the Permian to the Palaeogene periods subsequently eroded before present day.

BasinMod plots of the thermal maturity vs. time indicate that the high heat flow associated with extension caused the most rapid increase in the maturity of the coals as indicated by vitrinite reflectance. Igneous intrusions were seen to have a localised heating effect on the surrounding rocks.

HotPot was used successfully to produce overburden and palaeo-temperature maps across the eastern Midland Valley (Figures 9 and 12). The maximum depth of burial of the lowest Carboniferous rocks (Lower Limestone Formation and older strata) was calculated to be 5532$6049 \mathrm{~m}$ resulting in temperatures ranging between 140 and $147^{\circ} \mathrm{C}$ across the basin centre.

The results of BasinMod and HotPot were compared at two sites: Milton of Balgonie Borehole and Tower 1 Borehole. In general, agreement between the BasinMod and HotPot models at the two chosen sites was reasonable, although BasinMod tended to predict greater temperatures. The BasinMod results at the base of the Limestone Coal Formation were compared to those obtained by HotPot for the Passage Formation to Limestone Coal Formation model layer. HotPot predicted a maximum depth of burial of $2498 \mathrm{~m}$, with a temperature of $90{ }^{\circ} \mathrm{C}$ at Milton of Balgonie, compared to a maximum burial of $2300 \mathrm{~m}$ and $95{ }^{\circ} \mathrm{C}$ as predicted by BasinMod. HotPot predicted a maximum depth of burial of $2567 \mathrm{~m}$ with a temperature of $91{ }^{\circ} \mathrm{C}$ at Tower 1 Borehole compared to $2900 \mathrm{~m}$ and $110^{\circ} \mathrm{C}$ predicted by BasinMod.

In terms of thermal maturity of the basin, the HotPot model predicted the lowest Carboniferous strata would reach the oil window (temperature above $100^{\circ} \mathrm{C}$ ) after 327 Ma before present (base Namurian), which agrees with the BasinMod predicted temperatures for Milton of Balgonie. However, the BasinMod model predicted that the Limestone Coal and Passage formations did not reach $100{ }^{\circ} \mathrm{C}$ until burial during the Jurassic, which is later than predicted by HotPot. The HotPot model predicted that all the Lower Carboniferous strata and almost half the Passage to 
Limestone Coal formations unit reached the oil window during maximum burial at 60 Ma before present. BasinMod likewise predicts maximum maturity was reached during Cainozoic deep burial, with the exception of strata in contact with igneous intrusions. In general, BasinMod predicts higher maturity than HotPot, however, this discrepancy is partly a result of different approaches to calculating maturity. The temperatures and timing of maturation provide numerical data to support the model of Underhill et al. (2008) for the generation of hydrocarbons around the Midlothian-Leven syncline.

The estimates of sedimentation rates are 0.03-0.44 $\mathrm{m} \mathrm{ka}^{-1}$ from BasinMod and $0.2 \mathrm{~m} \mathrm{ka}^{-1}$ rising to $0.6 \mathrm{~m} \mathrm{ka}^{-1}$ from HotPot for the strata from the Lower Carboniferous into the Coal Measures. The sedimentation rate estimates from the two modelling procedures broadly agree, but are lower than the characteristic sedimentation rate given in Miall (1999) for pull-apart basins. Carboniferous strata in the MVS show local variation in facies, split coal seams and at times a fairly rapid sedimentation rate. The HotPot model shows evidence of extensional style initial synrift deposition in sub-basins followed by broad basin-wide thermal sag subsidence. These factors lead the authors to conclude that basin formation was influenced by extensional and strike-slip stresses. However, it is not possible to determine which process was dominant. BasinMod and HotPot are complementary modelling packages, using results from both can give a more complete view of the sedimentary basin history than either package individually. The results obtained here for the MVS could be improved on further if more time and more maturity data were available to allow further iteration of the model results. In particular, use of BasinMod at additional sites would provide data to enable the single overburden layer used in the HotPot model to be subdivided, and thus allow HotPot modelling of the Variscan episode of uplift and erosion.

\section{Conclusions}

Overall, the agreement between the HotPot and BasinMod results is good, implying that the models produced represent a plausible geological history of the MVS. HotPot is useful for 
modelling across the basin using grids from structural interpretation, giving a 'broad-brush' history and overview. BasinMod allows each borehole to be considered in more detail. Maximum thermal maturity was reached during deep Palaeogene burial before recent uplift with the exception of strata very close to igneous intrusions. Model results for sedimentation rates from both packages and current understanding of the geological evolution of this region indicated that Midlothian-Leven synclinal basin development was influenced by strike-slip and extensional stresses.

\section{Acknowledgements}

The authors would like to thank Mike Browne and Maxine Akhurst, BGS Edinburgh, for their support and invaluable contributions to this paper, and Paul Lappage and Henry Holbrook, BGS Keyworth for their assistance with diagrams. The authors would also like to thank the anonymous reviewers for their advice. This paper is published with permission of the Executive Director, British Geological Survey (NERC).

\section{References}

ALLEN, P.A. AND ALLEN, J.R. 1990. Basin analysis: principles and applications. Blackwell Science, Oxford.

ARTHAUD, F. AND MATTE, P. 1977. Late Palaeozoic strike-slip faulting in southern Europe and northern Africa: result of right-lateral shear between the Appalachians and the Urals. Bulletin of the Geological Society of America, 88, 1305-1320.

BALDWIN, B AND BUTLER, C.O. 1985. Compaction curves. Bulletin of the American Association of Petroleum Geologists, 69, 622-626. 
BALLING, N., KRISTIANSEN, J.I., BREINER, N., POULSEN, K.D., RASMUSSEN, R. AND SAXOV, S. 1981. Geothermal measurements and subsurface temperature modelling in Denmark. GeoSkrifter Aarhus Universitet, 16, 1-172.

BRITISH GEOLOGICAL SURVEY. 1987. Arran Special Sheet 1:50, 000 scale. Solid Geology.

BRITISH GEOLOGICAL SURVEY. 1985. Clyde. Sheet $55^{\circ} \mathrm{N}-06^{\circ} \mathrm{W}$. 1:250,000 series. Solid Geology.

BRITISH GEOLOGICAL SURVEY. 1999. Sheet 40E Kirkcaldy solid edition. British Geological Survey. Scotland 1:50 000 series.

BROWNE, M.A.E., DEAN, M.T., HALL, I.H.S., MCADAM, A.D., MONRO, S.K. AND CHISHOLM, J.I. 1999. A lithostratigraphical framework for the Carboniferous rocks of the Midland Valley of Scotland. British Geological Survey Research Report, RR/99/07.

CAMERON, I.B. AND STEPHENSON, D. 1985. British Regional Geology: The Midland Valley of Scotland (third edition). HMSO for British Geological Survey, London.

CARR A.D. 2000. Suppression and retardation of vitrinite reflectance, part 1. Formation and significance for hydrocarbon generation. Journal of Petroleum Geology, 23 (3), 313-343

CARTWRIGHT J., STEWART S. AND CLARK J. 2001. Salt dissolution and salt-related deformation of the Forth Approaches Basin, UK North Sea. Marine and Petroleum Geology, 18, 757-778. 
CHADWICK, R.A. 1985. Permian, Mesozoic and Tertiary structural evolution of England and Wales in relation to the principles of extension and inversion tectonics. In Whittaker, A. (ed) Atlas of onshore sedimentary basins in England and Wales: post-Carboniferous tectonics and stratigraphy. Blackie \& Son, Glasgow. 9-25.

CHADWICK, R.A., $\quad$ EVANS, D.J., ～ROWLEY, W.J., $\quad$ SMITH, N.J.P., $\quad$ WALKER, A.S.D., BIRCH, B. AND BULAT, J. 1999. Structure and evolution of the basin. In Plant, J.A., Jones, D.G. and Haslam, H.W. (eds) The Cheshire Basin: Basin evolution, fluid movement and mineral resources in a Permo-Triassic rift setting. The British Geological Survey, Keyworth, Nottingham. 41-89.

CORFIELD, S.M., GAWTHORPE, R.L., GAGE, M., FRASER, A.J. AND BESLY, B.M. 1996. Inversion tectonics of the Variscan foreland of the British Isles. Journal of the Geological Society of London, 153, 17-32.

COWARD, M.P. 1993. The effect of late Caledonian and Variscan continental escape tectonics on basement structure, Palaeozoic basin kinematics and subsequent Mesozoic basin development in NW Europe. In Parker, J.R. (ed) Petroleum Geology of NW Europe: Proceedings of the $4^{\text {th }}$ Conference. The Geological Society, London. 1095-1108.

COWARD M.P., DEWEY J.F. HEMPTON M. AND HOLROYD J. 2003. Tectonic Evolution Late Cretaceous. In: The Millennium Atlas: Petroleum Geology of the Central and Northern North Sea,. GSL Miscellaneous Titles. 29. 
DEWEY, J.F. 1982. Plate tectonics and the evolution of the British Isles. Journal of the Geological Society of London, 139, 371-412.

GATLIFF, R.W., RICHARDS, P.C., SMITH, K., GRAHAM, C.C., MCCORMAC, M., SMITH, N.J.P., LONG, D., CAMERON, T.D.J., EVANS, D., STEVENSON, A.G., BULAT, J. AND RITCHIE, J.D. 1994. United Kingdom Offshore Regional Report: the geology of the central North Sea. HMSO for the British Geological Survey, London.

HALLETT, D., DURANT, G.P. AND FARROW, G.E. 1985. Oil exploration and production in Scotland. Scottish Journal of Geology, 21, 547-570.

HILLIS, R.R., THOMPSON, K. AND UNDERHILL, J.R. 1994. Quantification of Tertiary erosion in the inner Moray Firth using sonic velocity data from the Chalk and the Kimmeridge Clay. Marine and Petroleum Geology, 11 (3), 283-293.

HOLLIDAY, D.W. AND MOLYNEUX, S.G. 2006. Editorial statement: new official names for the subsystems, series and stages of the Carboniferous System - some guidance for contributors to the Proceedings. Proceedings of the Yorkshire Geological Society, 56, 57-58

JARVIS, G.T. AND MCKENZIE D.P. 1980. Sedimentary Basin Formation with Finite Extension Rates. Earth and Planetary Science Letters, 48, 42-52. 
LANG, W.H. 1980. Determination of prior depth of burial using interval transit time. Oil and Gas Journal, 78 (4), 222-232.

LEEDER, M.R. 1982. Upper Palaeozoic basins of the British Isles - Caledonide Inheritance versus Hercynian Plate Margin Processes. Journal of the Geological Society of London, 139, 479-491.

MAGARA, K. 1976. Thickness of removed sedimentary rocks, palaeopore pressure and palaeotemperature, southwestern part of western Canada Basin. Bulletin of the American Association of Petroleum Geologists, 60 (4), 554-565.

MARIE, J.P.P. 1975. Rotliegendes stratigraphy and diagenesis. In Woodland, AW (ed) Petroleum geology and the continental shelf of Northwest Europe, 1, 205-211. : Applied Science Publishers, London.

MCKENZIE, D.P. 1978. Some remarks on the development of sedimentary basins. Earth and Planetary Science Letters, 40, 25-32.

METEOROLOGICAL OFFICE. 2004. Climate averages: station, district and regional averages for the periods 1961-1990 and 1971-2000. World Wide Web Address www.metoffice.gov.uk/climate/uk/averages.

MIALL, A.D. 1999. Principles of sedimentary basin analysis. Third edition. Springer-Verlag, Berlin Heidelberg New York. 
MYKURA, W., CALVER, M.A. AND WILSON, R.B. 1967. The Upper Carboniferous rocks of south-west Ayrshire. Bulletin of the Geological Survey of Great Britain, 26, 23-98.

OWENS, B., MCLEAN, D., SIMPSON, K.R.M., SHELL, P.M.J. AND ROBINSON, R., 2005. Reappraisal of the Mississippian palynostratigraphy of the East Fife coast, Scotland, United Kingdom. Palynology 29, 23-47.

PENN, I.E., HOLLIDAY, D.W., KIRBY, G.A., KUBALA, M., SOBEY, R.A., MITCHELL, W.I., HARRISON, R.K. AND BECKINSALE, R.D. 1983. The Larne No. 2 borehole: discovery of a new Permian volcanic centre. Scottish Journal of Geology, 19, 333-346.

RAYMOND, A.C. AND MURCHISON, D.G. 1988. Development of organic maturation in the thermal aureoles of sills and its relation to sediment compaction. Fuel, 67, 1599-1608

RAYMOND A.C. 1991. Carboniferous rocks of the eastern and central Midland Valley of Scotland: Organic petrology, organic geochemistry and effect of igneous activity. University of Newcastle Upon Tyne. PhD thesis (Unpublished).

READ, W.A., $\quad$ BROWNE, M.A.E., $\quad$ STEPHENSON, D. $\quad$ AND UPTON, B.G.J. 2002. Carboniferous. In Trewin, N.H. (ed) The Geology of Scotland. The Geological Society London. 251-300 
RIPPON, J., READ, W.A. AND PARK, R.G. 1996. The Ochil Fault and the Kincardine basin: key structures in the tectonic evolution of the Midland Valley of Scotland. Journal of the Geological Society of London, 153, 573-587.

RITCHIE, J.D., JOHNSON, H. BROWNE, M.A.E. AND MONAGHAN, A.A. 2003. Late Devonian-Carboniferous tectonic evolution within the Firth of Forth, Midland Valley; as revealed from 2D seismic reflection data. Scottish Journal of Geology, 39 (2), 121-134.

ROLLIN, K., KIRBY, G.A., ROWLEY, W.J. AND BUCKLEY, D.K. 2002. United Kingdom. In Hurter, S. and Haenel, R. (eds) Atlas of Geothermal Resources in Europe (Luxembourg: EC Research Directorate-General). Publication number EUR17811. 61-64.

ROWLEY, W.J., CHADWICK, R.A. AND HOLLIDAY, D.W. 1993. Basin thermal modelling using HotPot version 3.0. British Geological Survey Technical Report WC/93/04.

SCLATER, J.G. AND CHRISTIE, F.A.F. 1980. Continental stretching: an explanation of the post-mid-Cretaceous subsidence of the Central North Sea Basin. Journal of Geophysical Research, 85, 3711-3739.

SMEDLEY, P.L. 1986. Petrochemistry of Dinantian volcanism in northern Britain. University of Edinburgh. PhD thesis (Unpublished).

SMITH, R.A. 1995 The Siluro-Devonian evolution of the southern Midland Valley of Scotland: Geological Magazine, 132, 503-513 
STEPHENSON, D., $\quad$ LOUGHLIN, $\quad$ S.C., $\quad$ MILLWARD, D., $\quad$ WATERS, C.N. AND WILLIAMSON, I.T. 2003. Carboniferous and Permian igneous rocks of Great Britain North of the Variscan Front. Geological Conservation Review, Series 27. Joint Nature Conservation Committee, Peterborough.

TREWIN, N.H. \& ROLLIN, K.E. 2002. Geological history and structure of Scotland. In Trewin, N.H. (ed) The Geology of Scotland. The Geological Society, London. 1-26.

TIMMERMAN, M.J. 2004. Timing, geodynamic setting and character of Permo-Carboniferous magmatism in the foreland of the Variscan Orogen, NW Europe. In Wilson, M., Neumann E.-R., Davies G.R., Timmerman, M.J., Heeremans, M. and Larsen, B.T. (eds) Permo-Carboniferous Magmatism and Rifting in Europe. The Geological Society, London, Special Publications, 223, 41-74.

UNDERHILL, J.R., MONAGHAN, A.A. AND BROWNE, M.A.E. 2008. Controls on structural styles, basin development and petroleum prospectivity in the Midland Valley of Scotland. Marine and Petroleum Geology, 25, 1000-1022

UPTON, B.G.J., STEPHENSON, D., SMEDLEY, P.M., WALLIS, S.M. AND FITTON J.G. 2004. Carboniferous and Permian magmatism in Scotland. In Wilson, M., Neumann E.R., Davies G.R., Timmerman, M.J., Heeremans, M. and Larsen, B.T. (eds) Permo-Carboniferous Magmatism and Rifting in Europe. Geological Society, London, Special Publications, 223, 195217 
WHITE, R.S. 1988. A hotspot model for early Tertiary volcanism in the N Atlantic. In Morton, A.C. and Parson, L.M. (eds) Early Tertiary Volcanism and the Opening of the NE Atlantic. Geological Society, London, Special Publications, 39, 3-13.

ZIEGLER, P.A. 1990. Geological Atlas of Western and Central Europe. Second Edition, Shell Internationale Petroleum, Maatschappij, B.V., The Hague.

\section{Figure captions}

Figure 1: Geological map and boreholes studied in the eastern Midland Valley of Scotland, showing Hotpot model area.

Figure 2: Summary of Carboniferous stratigraphy of the eastern Midland Valley after Read et al. (2002), Browne et al. (1999) using subsystem names from Holliday and Molyneux (2006).

Figure 3: (a) Eskmouth Borehole BasinMod burial history, (b) Eskmouth Borehole maturity model, (c) Eskmouth Borehole modelled palaeo-heat flow. Stratigraphical units as shown in Figure 2. Chronostratigraphical divisions; C - Carboniferous, Perm - Permian, T - Triassic, J Jurassic, K - Cretaceous, Pal - Palaeogene, N - Neogene. Vitrinite Reflectance (VR, units \%Ro) is the percentage of light reflected by the sample compared to a $100 \%$ reflective surface, i.e. a mirror, VR indicates the reflection off macerals in the coal sample from a normal incident beam of non-polarised light. LLGS - Lower Limestone Formation, LSC - Limestone Coal Formation, 
ULGS - Upper Limestone Formation, PGP - Passage Formation, LCMS - Lower Coal Measures Formation (Scotland), MCMS - Midland Coal Measures Formation (Scotland),

Figure 4: (a) Firth of Forth Tower 1 Borehole BasinMod burial history, (b) Tower 1 Borehole maturity model, (c) Tower 1 Borehole modelled palaeo-heat flow. Chronstratigraphical divisions as in Figure 3. LSC - Limestone Coal Formation, Sill - sill, ULGS - Upper Limestone Formation, PGP - Passage Formation, LCMS - Lower Coal Measures Formation (Scotland).

Figure 5: (a) Milton of Balgonie borehole 1 BasinMod model burial history, (b) Milton of Balgonie borehole maturity model, (c) Milton of Balgonie borehole modelled palaeo-heat flow. Chronstratigraphical divisions as in Figure 3. Sill - sill, SYG - Strathclyde Group, LLGS Lower Limestone Formation, MVSill - Midland Valley Sill, LSC - Limestone Coal Formation, ULGS - Upper Limestone Formation, PGP - Passage Formation.

Figure 6: Standard density vs. depth curves for sandstone (solid line), mudstone (short-dashed line) and mudstone with $10 \%$ sandstone (long-dashed line), as used for UK basins. Diamond markers show observed density log values for shaly horizons in Kilconquhar Borehole, and triangle markers show these values depth-shifted for 1950 m of eroded overburden.

Figure 7: Map of estimated thickness of eroded overburden (contours at $50 \mathrm{~m}$ intervals), present day coastline also shown. Area of map shown in Figure 1.

Figure 8: Stratigraphical columns at stages in basin burial history generated by HotPot backstripping process. 
Figure 9: A sequence of maps to illustrate the development of the basin, taken from the backstripped and decompacted burial history produced by HotPot. Contour interval $200 \mathrm{~m}$ on all maps. Present day coastline shown. (a): Thickness of sediment representing the Limestone Coal - Passage formations immediately after deposition, 316 Ma. (b): Thickness of sediment representing the Lower-Middle Coal Measures and the Limestone Coal - Passage formations, 314 Ma. (c): Thickness of sediment representing the Middle-Upper Coal Measures to the Limestone Coal - Passage formations, 311 Ma. (d): Thickness of sediment representing the restored overburden to the Limestone Coal - Passage formations, $60 \mathrm{Ma}$.

Figure 10: Burial history in basin depocentre, at British National Grid co-ordinates [334950, 690750]. The lines represent the variation with time in the depths of the bases of the stratigraphic units indicated.

Figure 11: Estimate of heatflow over time adopted for HotPot modelling.

Figure 12: A sequence of maps to illustrate the thermal history of the basin. Figures 12 (a-d) show the temperature variation at the base of the Limestone Coal - Passage formations with increasing burial over geological time. Present day coastline shown. Compare these with the burial history maps in Figure 9. Contour interval $5^{\circ} \mathrm{C}$ on all maps. (a) at $316 \mathrm{Ma}$. (b) at 314 Ma. (c) at 311 Ma. (d) at 60 Ma.

Figure 13: HotPot pseudo-maturity map of the Limestone Coal - Passage formations at 311 Ma, when approximately one quarter of the subcrop was within the area delineated by the $100^{\circ} \mathrm{C}$ contour. Dark grey: temperature greater than $100^{\circ} \mathrm{C}$; pale grey: temperature less than $100^{\circ} \mathrm{C}$. 


\section{Table captions}

Table 1. Overburden thickness adopted at boreholes for HotPot burial history modelling. Wellsgreen Borehole logs; Schl - Schlumberger, BPB - BPB Slimline Logging.

Table 2. Summary of HotPot parameters by lithostratigraphic unit.

Table 3. Model stratigraphy used with HotPot burial history model

Table 4. Computed rates of deposition for HotPot model layers

Table 5. Estimated geothermal gradient at 60 Ma before present.

Table 6. Comparison of burial and thermal modelling results from BasinMod and HotPot. Values in square brackets are the coordinates of the nearest HotPot grid cell to the position of the borehole 

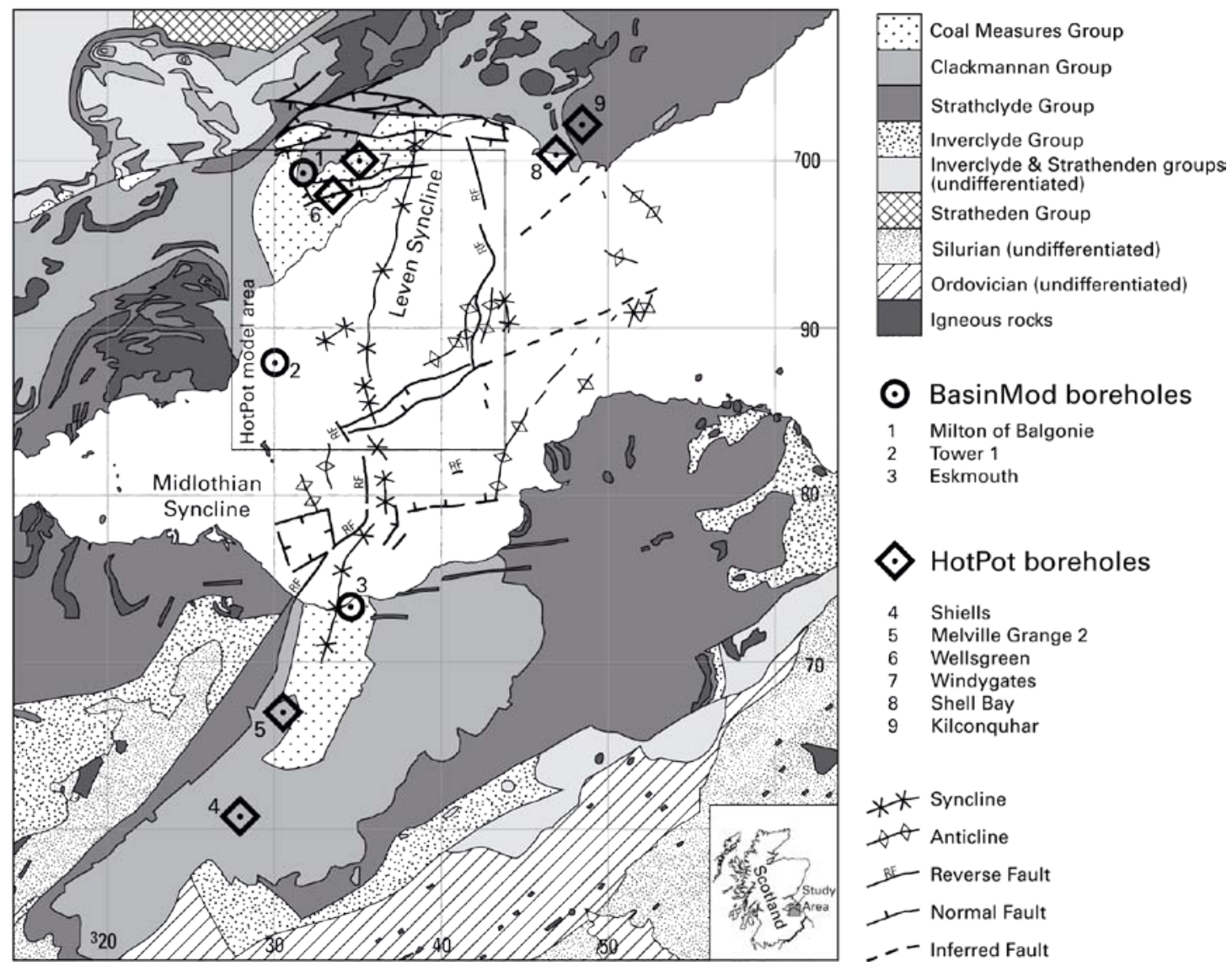

\section{$\odot$ HotPot boreholes}

4 Shiells

5 Melville Grange 2

6 Wellsgreen

7 Windygates

8 Shell Bay

9 Kilconquhar

* Syncline

$\diamond \theta$ Anticline

Bif- Reverse Fault

1 Normal Fault

_- - Inferred Fault

Figure 1 


\begin{tabular}{|c|c|c|c|c|c|c|}
\hline Period & Subsystem & Stage & Sub-stage & Group & Formations (Fife Region) & Stratigraphy \\
\hline \multirow{15}{*}{ Carboniferous } & \multirow{3}{*}{ Pennsylvanian } & Westphalian C & Bolsolvian & \multirow{3}{*}{ Coal Measures } & Upper Coal Measures (UCMS) & Grading to fluvial sandstones \\
\hline & & Westphalian B & Duckmantian & & Middle Coal Measures (MCMS) & Fluvio-deltaic mudstone/coal \\
\hline & & Westphalian A & Langsettian & & Lower Coal Measures (LCMS) & Fluvio-deltaic mudstone/coal \\
\hline & \multirow{12}{*}{ Mississippian } & \multirow{3}{*}{ Namurian } & $\begin{array}{l}\text { Chokerian - } \\
\text { Yeadonian }\end{array}$ & \multirow{4}{*}{$\begin{array}{l}\text { Clackmannan } \\
\text { Group }\end{array}$} & PASSAGE FORMATION (PGP) & $\begin{array}{l}\text { Coarse alluvial sandstone } \\
\text { Marine transgressions }\end{array}$ \\
\hline & & & Arnsbergian & & $\begin{array}{l}\text { UPPER LIMESTONE } \\
\text { FORMATION (ULGS) }\end{array}$ & Shallow marine limestones \\
\hline & & & Pendleian & & IIMFSTONF COAL FORMATION (ISC) & Fluvio/deltaic. Marine bands \\
\hline & & \multirow{6}{*}{ Visean } & \multirow{2}{*}{ Brigantian } & & $\begin{array}{l}\text { LOWER LIMESTONE } \\
\text { FORMATION (LLGS) }\end{array}$ & Marine-fluvio/deltaic deposits \\
\hline & & & & \multirow{5}{*}{$\begin{array}{l}\text { Strathclyde } \\
\text { Group (SYG) } \\
\text { (Formerly Oil } \\
\text { Shale Group) }\end{array}$} & PATHHEAD FORMATION & Mudstone, Siltstone Marine bands \\
\hline & & & \multirow{3}{*}{ Asbian } & & SANDY CRAIG FORMATION & Non-marine mudstone And siltstone \\
\hline & & & & & PITTENWEEM FORMATION & \multirow{2}{*}{$\begin{array}{l}\text { Mainly non-marine cycles; } \\
\text { mudstone, siltstone and sandstone }\end{array}$} \\
\hline & & & & & ANSTRUTHER FORMATION & \\
\hline & & & $\begin{array}{l}\text { Holkerian - } \\
\text { Arundian }\end{array}$ & & FIFE NESS FORMATION & $\begin{array}{l}\text { Upward fining, mainly fluvial } \\
\text { sandstone.cycles. Extensive } \\
\text { basaltic volcanic activity }\end{array}$ \\
\hline & & \multirow{4}{*}{ Tournaisian } & Chadian & & & \\
\hline & & & \multirow{2}{*}{\multicolumn{2}{|c|}{ Diachronous Transitional base }} & $\begin{array}{l}\text { BALLAGAN FORMATION } \\
\text { Diachronous Transitional base }\end{array}$ & $\begin{array}{l}\text { Lacustrine-lagoonal } \\
\text { mudstones and dolostones }\end{array}$ \\
\hline & & & & & \multirow[t]{2}{*}{ KINNESSWOOD FORMATION } & $\begin{array}{l}\text { Meandering river deposits. } \\
\text { Calcretes in siltstone/claystone }\end{array}$ \\
\hline Devonian & & & & $\begin{array}{l}\text { Stratheden } \\
\text { Group }\end{array}$ & & $\begin{array}{l}\text { Alluvial sandstones } \\
\text { and conglomerates. }\end{array}$ \\
\hline
\end{tabular}

Figure 2 

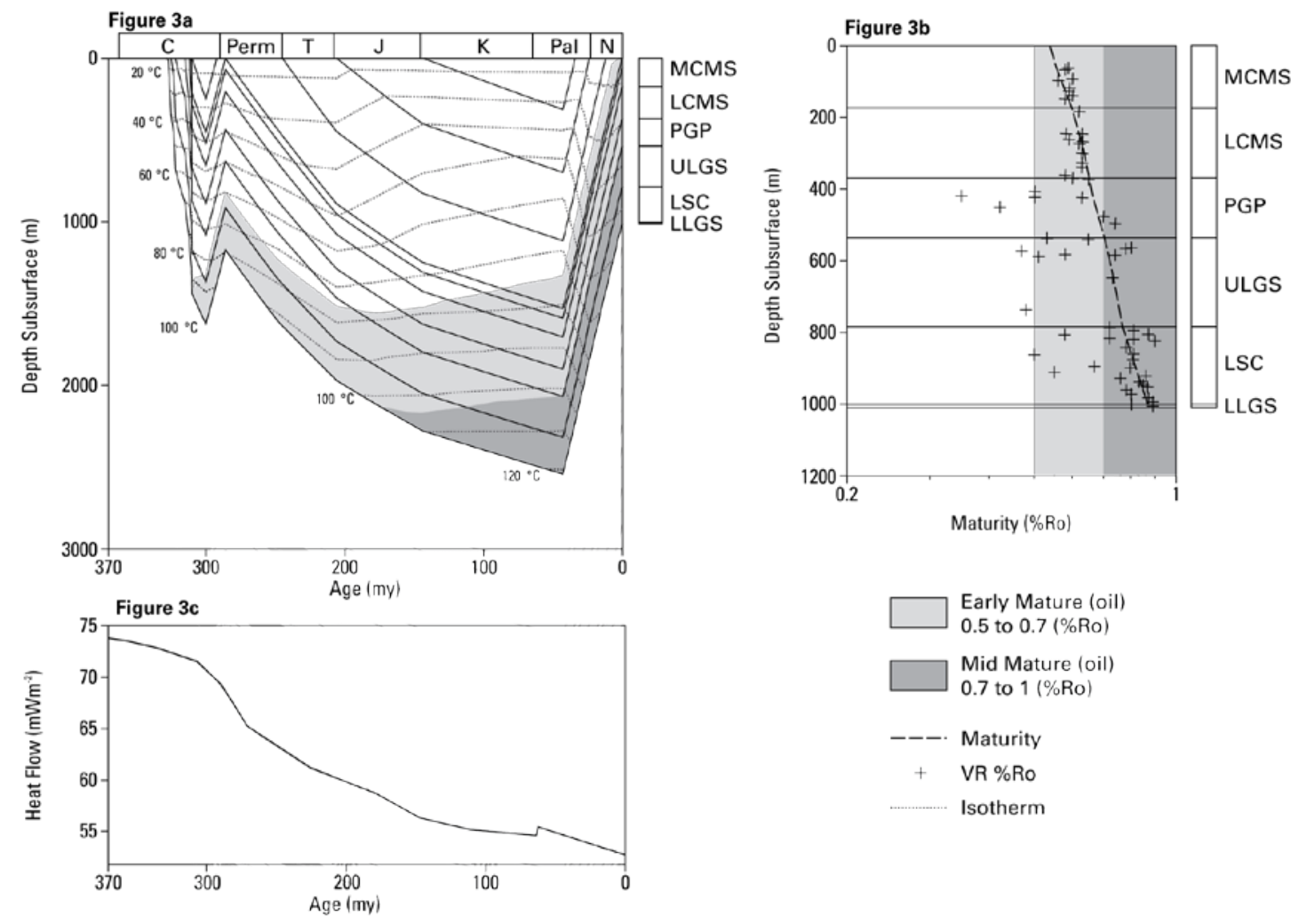

Early Mature (oil)

0.5 to 0.7 (\%Ro)

Mid Mature (oil)

0.7 to 1 ( $\%$ Ro)

--. Maturity

$+\quad$ VR \%Ro

Isotherm

Figure 3 

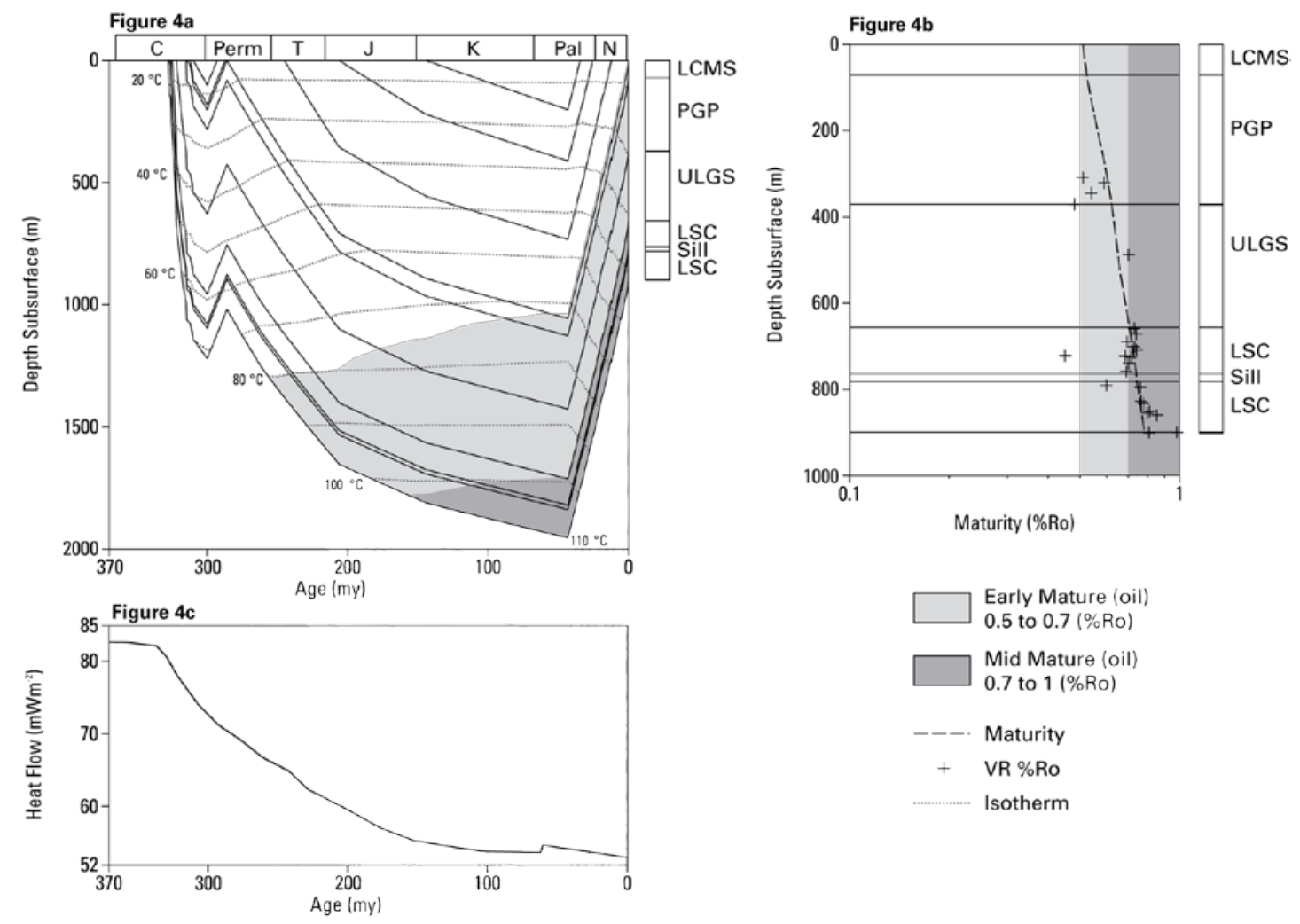

Early Mature (oil)

0.5 to 0.7 (\% Ro)

Mid Mature (oil)

0.7 to 1 (\%Ro)

--. Maturity

+ VR \%Ro

Isotherm

Figure 4 

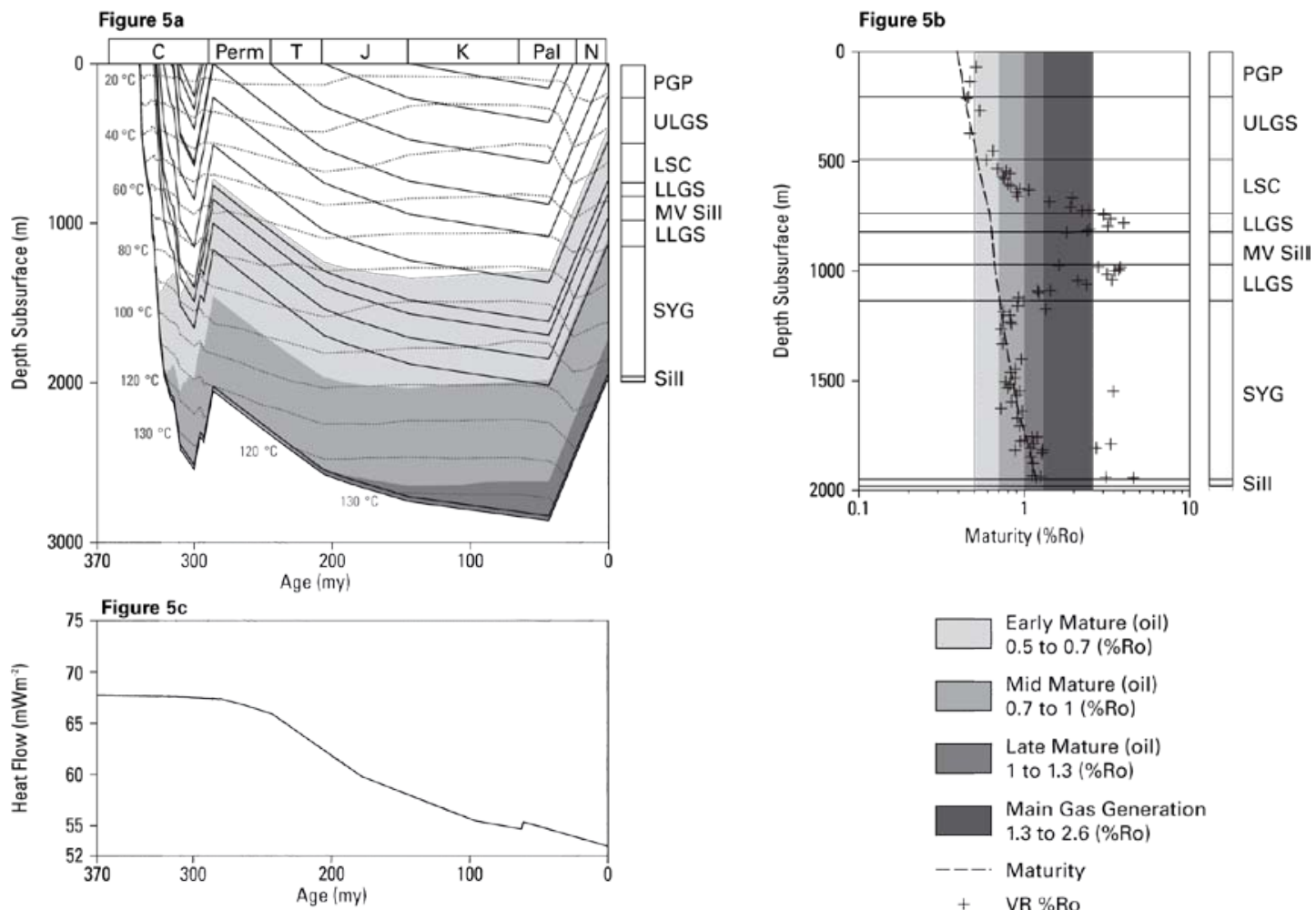

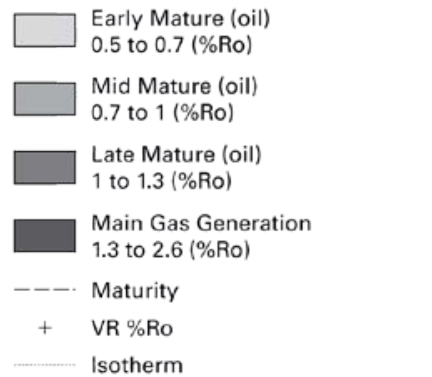

Figure 5 


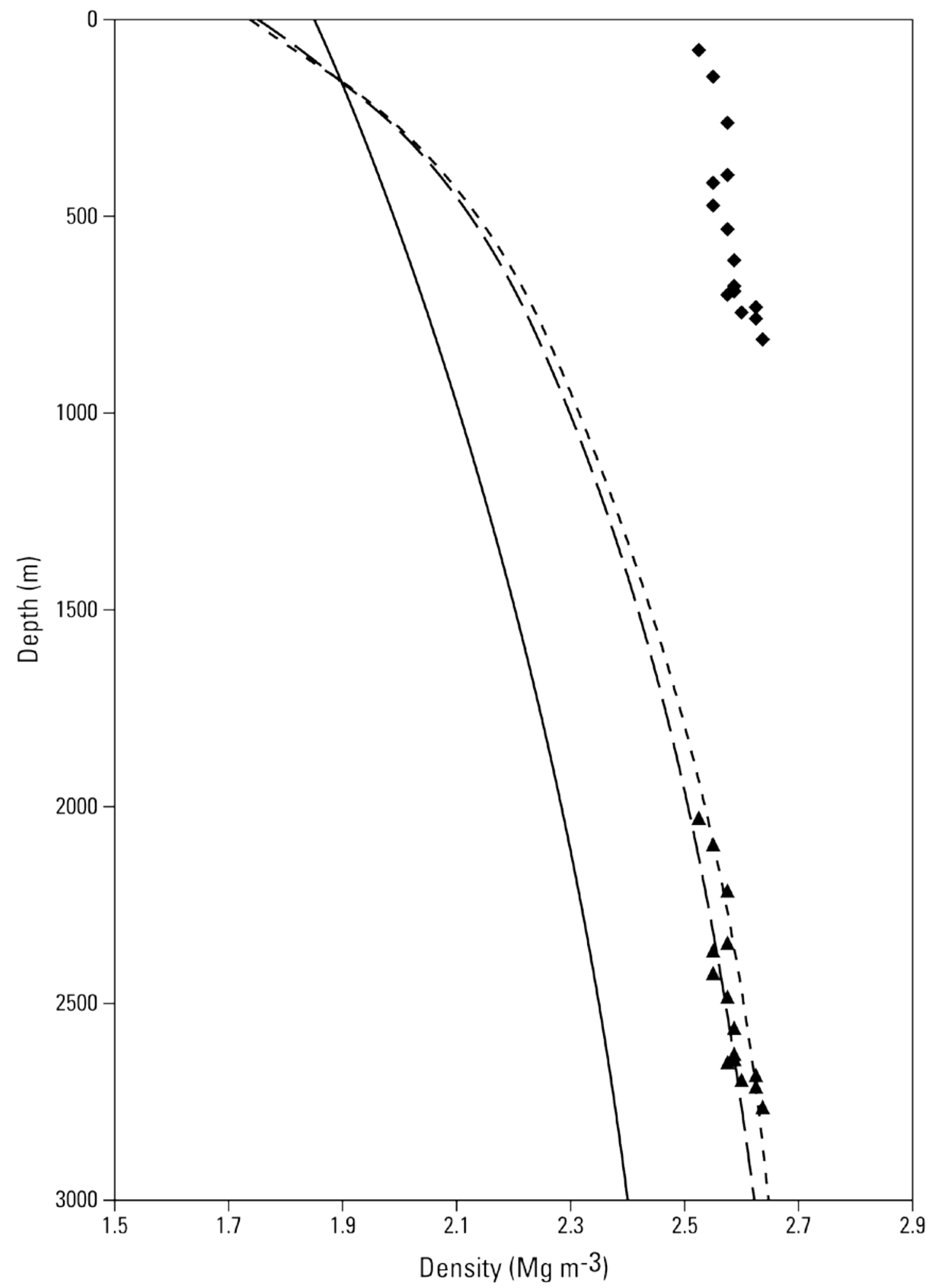

Figure 6 


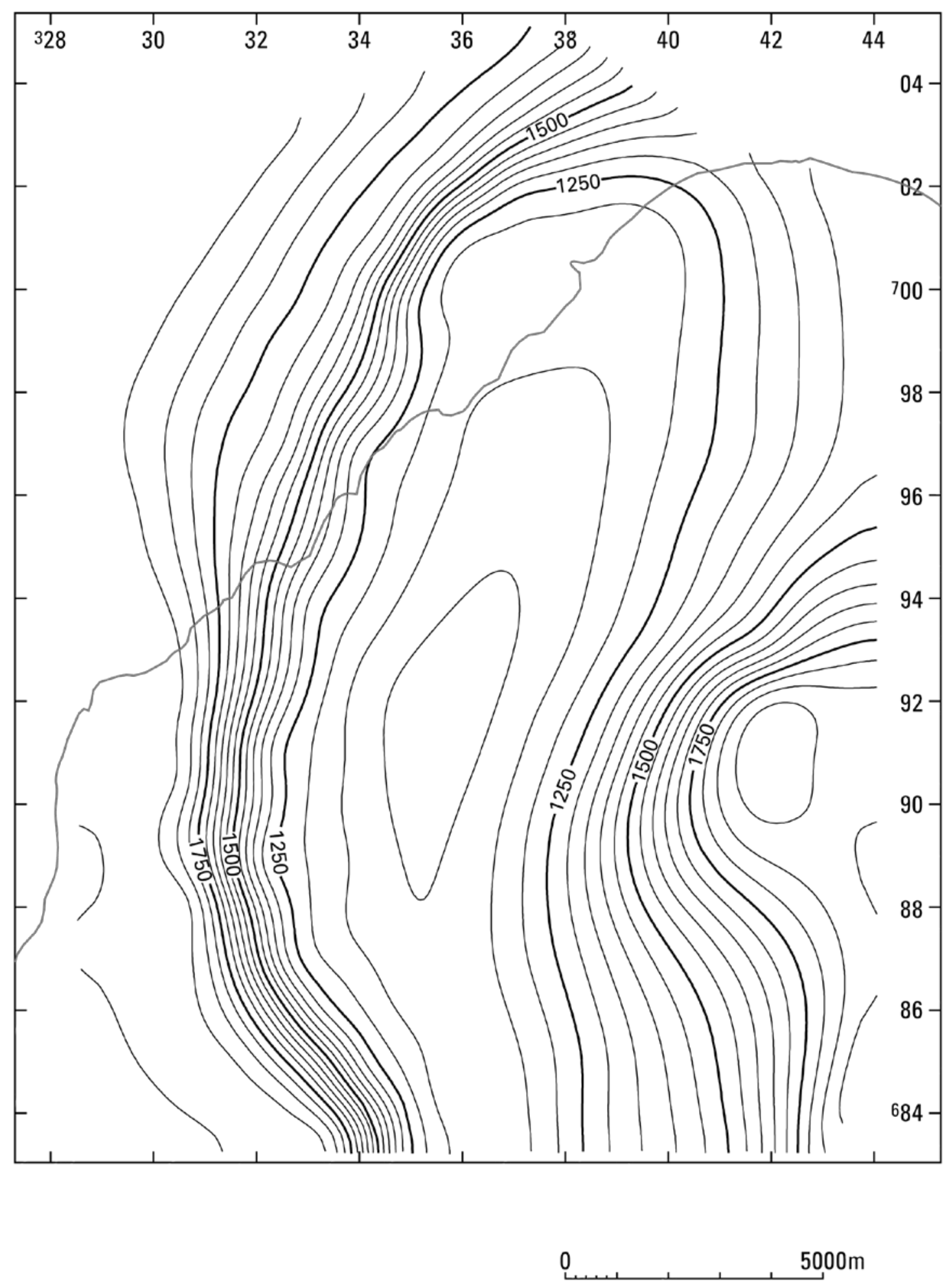

Figure 7 


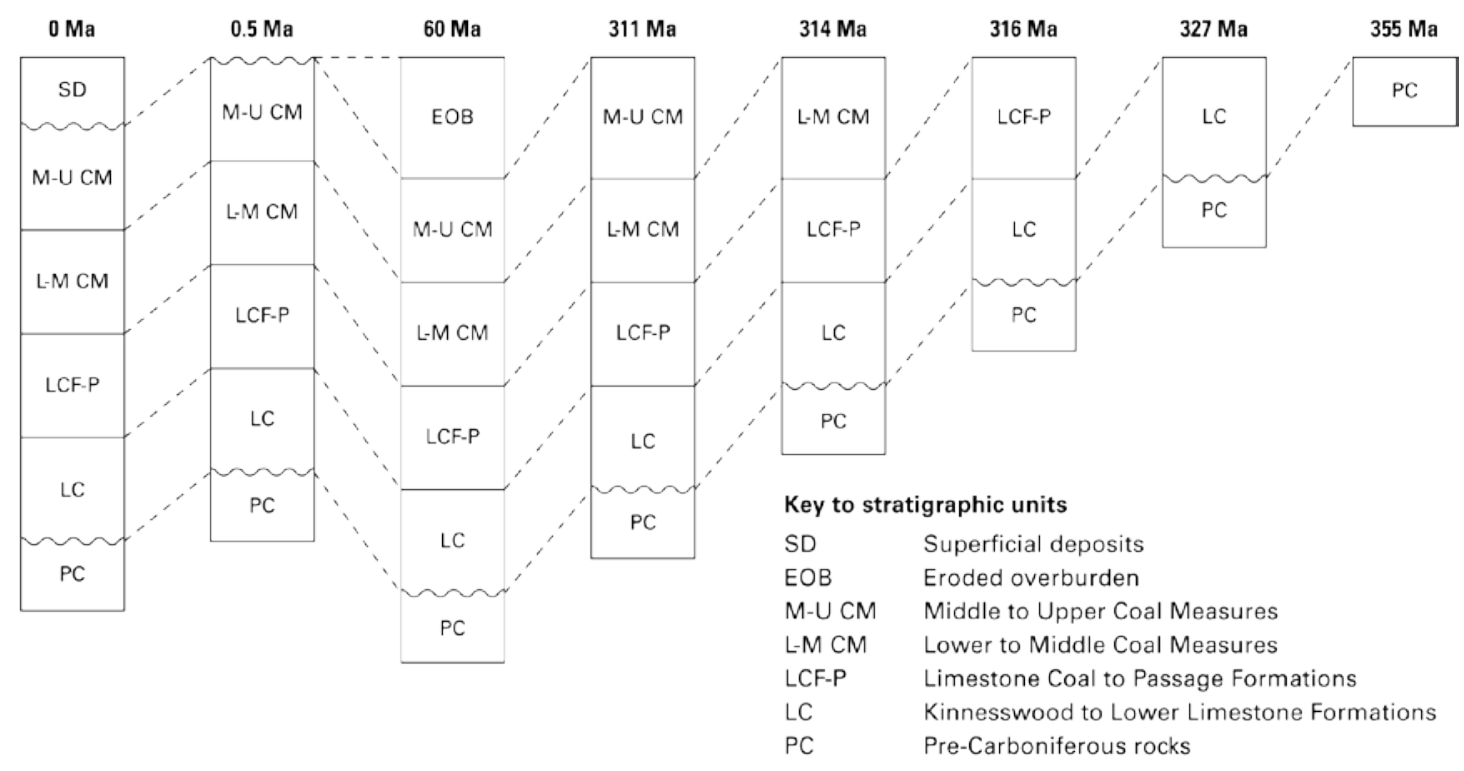

Figure 8 

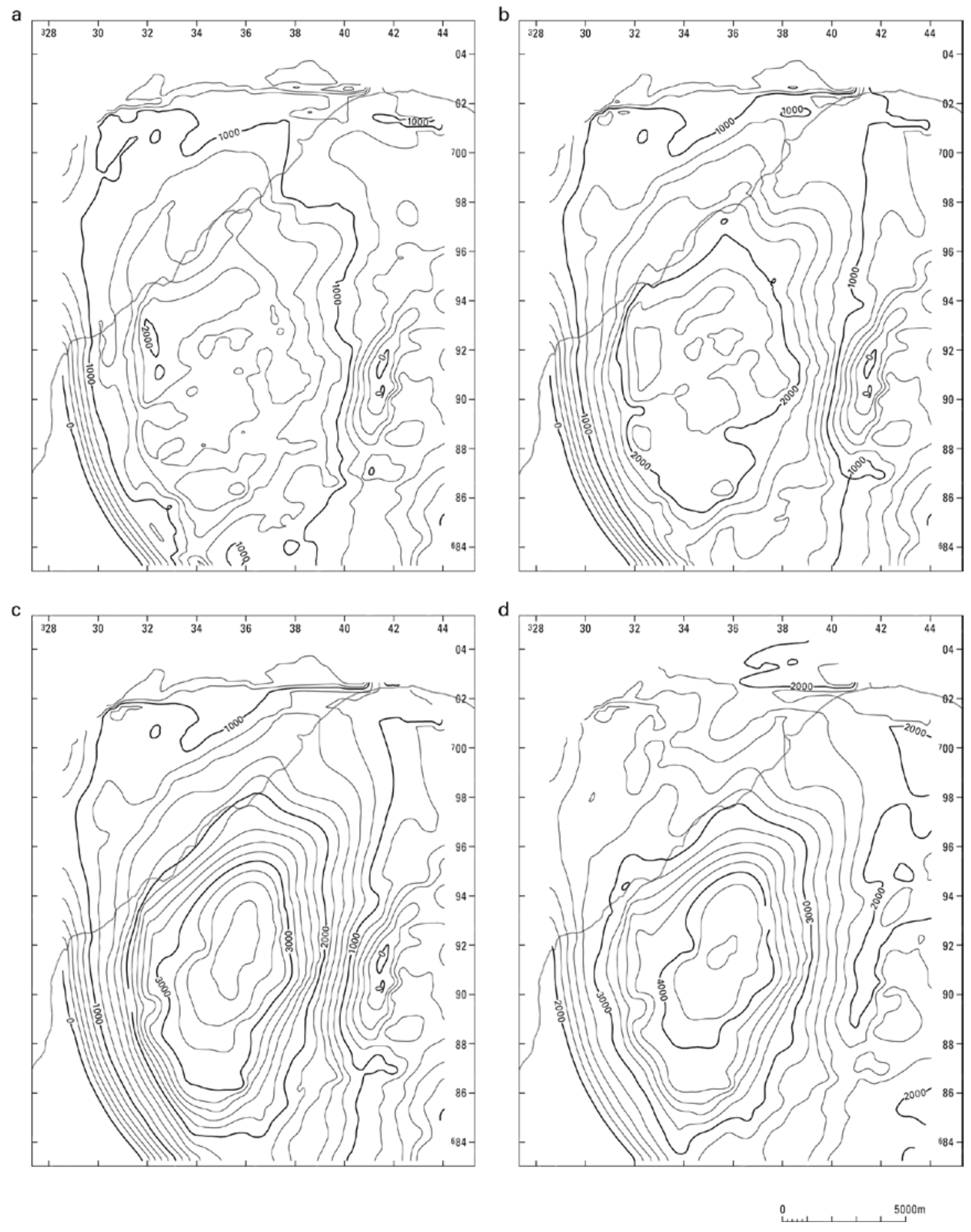

Figure 9 


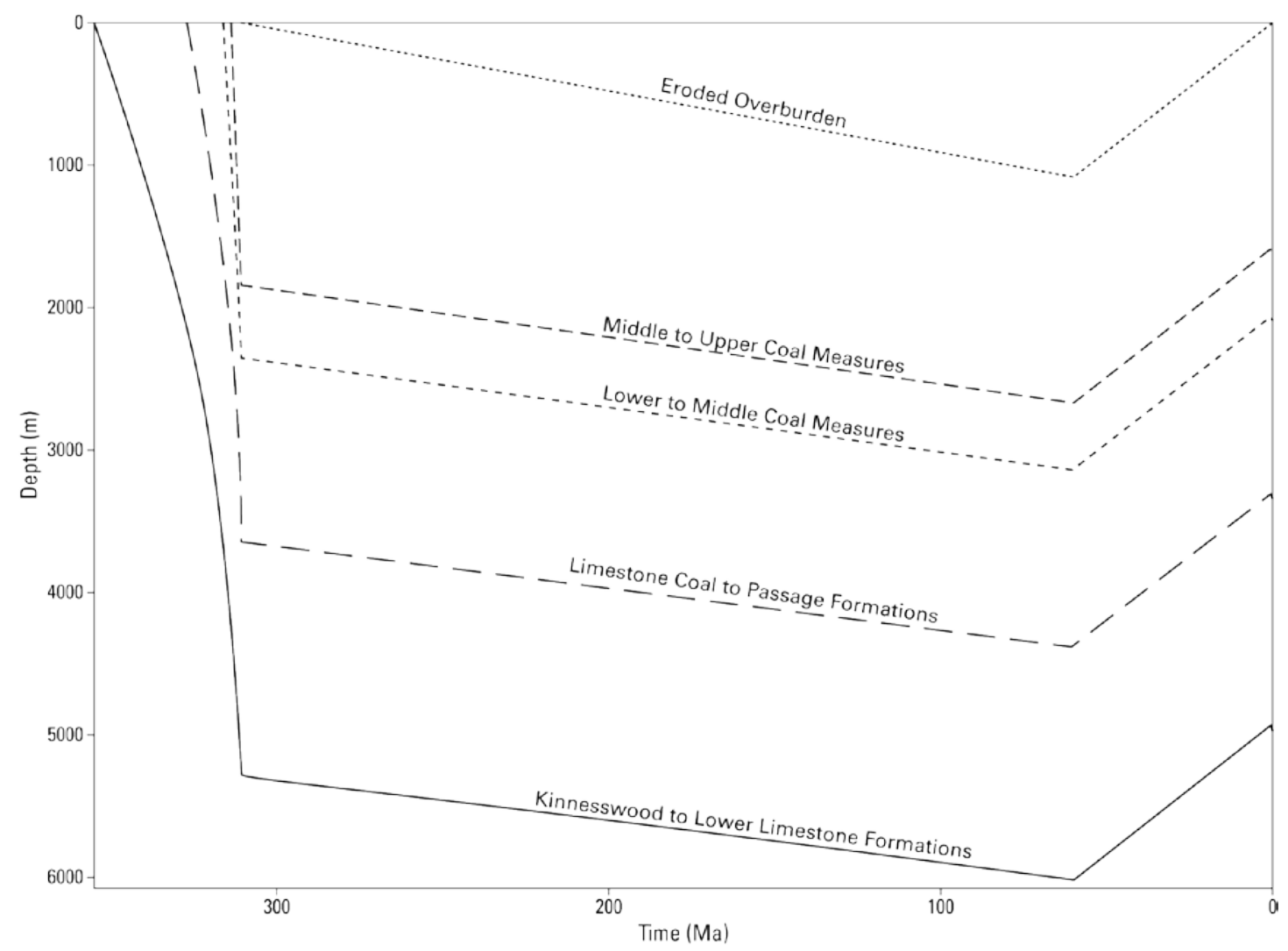

Figure 10 


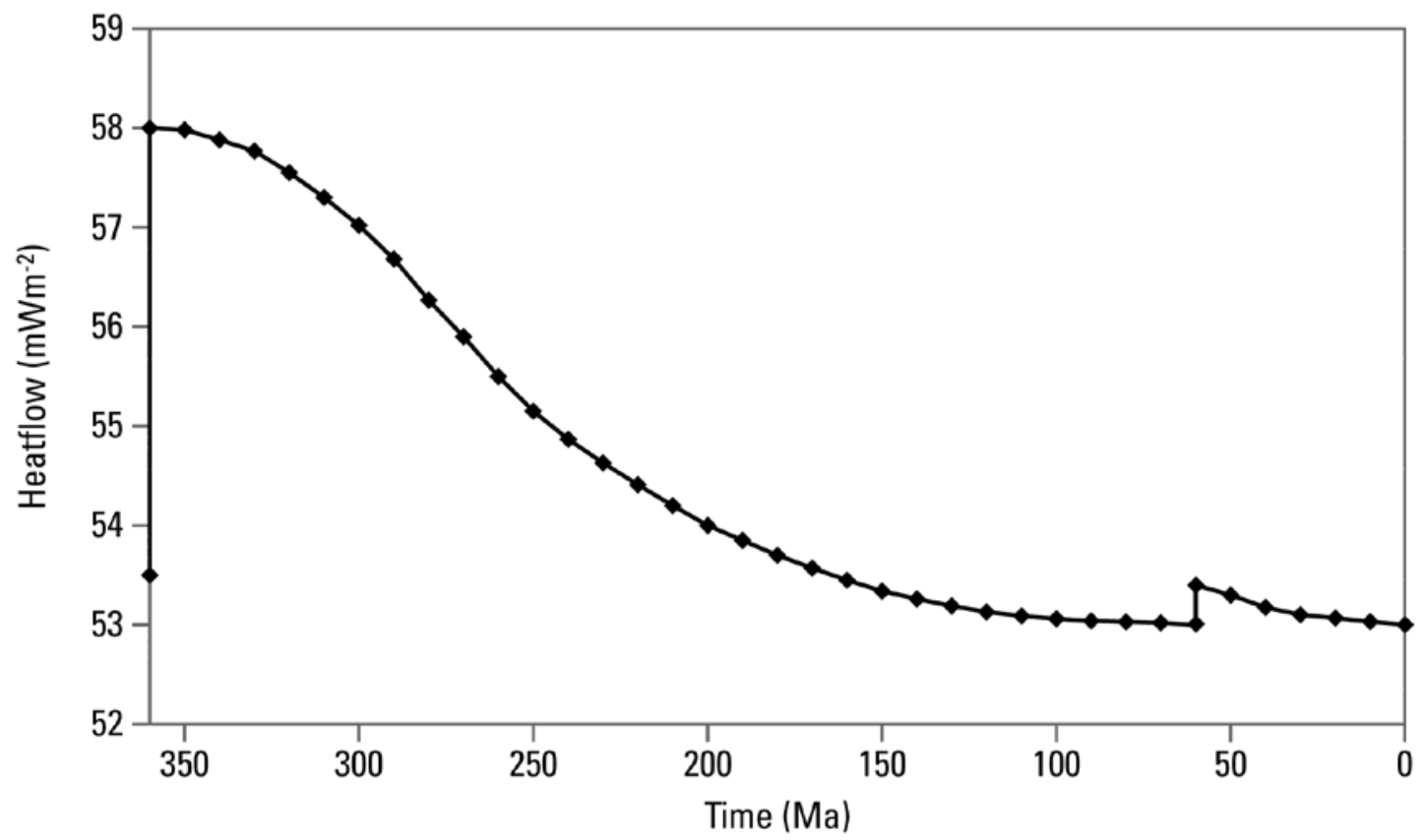

Figure 11 

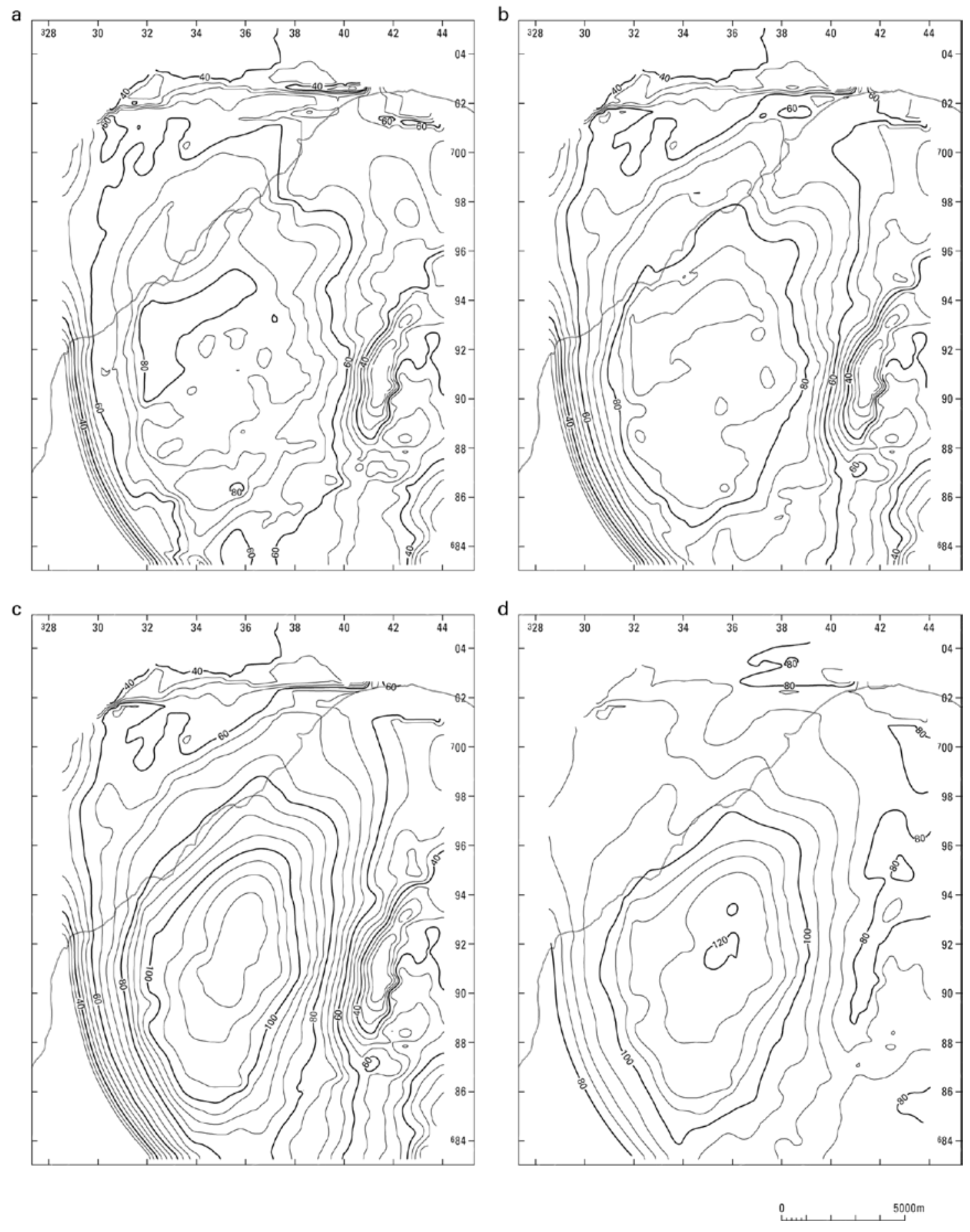


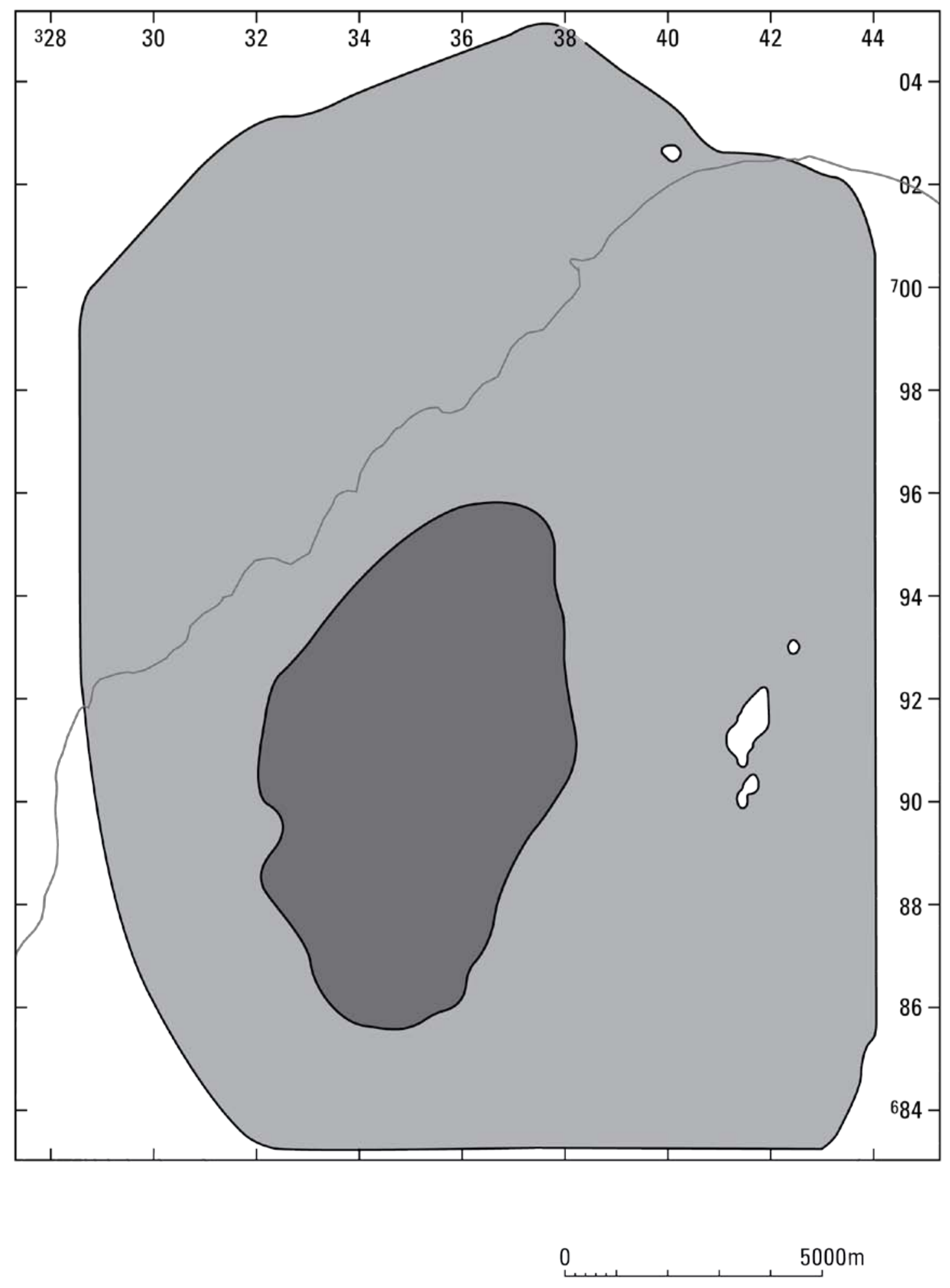

Figure 13 
Table 1: Overburden thickness adopted at boreholes for HotPot burial history modelling. Wellsgreen Borehole log; Schl - Schlumberger, BPB - BPB Slimline Logging

\begin{tabular}{|l|l|c|c|c|}
\hline Borehole & BGS Registration & Easting & Northing & $\begin{array}{c}\text { Overburden } \\
\text { thickness (m) }\end{array}$ \\
\hline Gartenkeir 1 & NS99SW/290 & 292665 & 694860 & 1250 \\
\hline Gartlove 2 & NS99SW/292 & 294034 & 692670 & 2000 \\
\hline Kilconquhar & NO40SE/26 & 348448 & 703046 & 1950 \\
\hline Melville Grange 2 & NT36NW/409 & 330574 & 667282 & 1600 \\
\hline Shell Bay & NO40SE/27 & 346777 & 700482 & 1550 \\
\hline Shiells & NT26SE/157 & 327890 & 660920 & 1950 \\
\hline Wellsgreen (BPB) & NT39NW/381 & 333421 & 698330 & 1900 \\
\hline Wellsgreen (Schl) & NT39NW/381 & 333421 & 698330 & 1400 \\
\hline Windygates & NO30SE/195 & 335101 & 700337 & 1300 \\
\hline
\end{tabular}


Table 2: Summary of HotPot parameters by lithostratigraphic unit

\begin{tabular}{|l|l|l|l|}
\hline Stratigraphic Unit & $\begin{array}{l}\text { Age Deposition } \\
\text { Commenced }\end{array}$ & $\begin{array}{l}\text { Age Erosion } \\
\text { Commenced }\end{array}$ & Lithology \\
\hline Superficial deposits & $0.5 \mathrm{Ma}$ & & $\begin{array}{l}80 \% \mathrm{mdst} \\
20 \% \mathrm{sst}\end{array}$ \\
\hline Eroded overburden & $311 \mathrm{Ma}$ & $60 \mathrm{Ma}$ & $\begin{array}{l}50 \% \mathrm{mdst} \\
40 \% \mathrm{sst} \\
10 \% \mathrm{st}\end{array}$ \\
\hline Middle to Upper Coal Measures & $314 \mathrm{Ma}$ & & $\begin{array}{l}60 \% \mathrm{mdst} \\
40 \% \mathrm{sst}\end{array}$ \\
\hline Lower to Middle Coal Measures & $316 \mathrm{Ma}$ & & $\begin{array}{l}70 \% \mathrm{mdst} \\
30 \% \mathrm{sst}\end{array}$ \\
\hline Limestone Coal to Passage & $327 \mathrm{Ma}$ & & $\begin{array}{l}40 \% \mathrm{mdst} \\
40 \% \mathrm{sst} \\
20 \% \text { Ist }\end{array}$ \\
\hline Formations & & & $\begin{array}{l}50 \% \mathrm{mdst} \\
30 \% \mathrm{sst} \\
20 \% \mathrm{lst}\end{array}$ \\
\hline Carboniferous strata below & $355 \mathrm{Ma}$ & & \\
Limestone Coal Formation & & & \\
\hline
\end{tabular}


Table 3: Model stratigraphy used with HotPot burial history model

\begin{tabular}{|c|c|c|}
\hline Unit Tops & Lithostratigraphic Units & Unit Bases \\
\hline DTM & Superficial deposits & \multirow[b]{2}{*}{ Rockhead } \\
\hline \multirow[b]{2}{*}{ Barncraig Coal } & $\begin{array}{l}\text { Upper Coal Measures Fm } \\
\text { Middle Coal Measures Fm }\end{array}$ & \\
\hline & $\begin{array}{l}\text { Middle Coal Measures Fm } \\
\text { Lower Coal Measures Fm }\end{array}$ & Barncraig Coal \\
\hline Dysart Main Coal & $\begin{array}{l}\text { Passage Formation } \\
\text { Upper Limestone Fm } \\
\text { Limestone Coal Fm }\end{array}$ & Dysart Main Coal \\
\hline Top Hosie Limestone & $\begin{array}{l}\text { Lower Limestone Fm } \\
\text { Strathclyde \& Inverclyde Grps }\end{array}$ & Base Limestone Coal \\
\hline Top Devonian Strata & Stratheden \& Lanark Grps & Base Carboniferous strata \\
\hline
\end{tabular}


Table 4: Computed rates of deposition for HotPot model layers

\begin{tabular}{|l|r|r|r|r|r|}
\hline Stratigraphic Unit & $\begin{array}{r}\text { Start } \\
(\mathbf{M a})\end{array}$ & $\begin{array}{r}\text { End } \\
(\mathrm{Ma})\end{array}$ & $\begin{array}{r}\text { Duration } \\
(\mathbf{M a})\end{array}$ & $\begin{array}{r}\text { Thickness } \\
(\mathbf{m})\end{array}$ & $\begin{array}{r}\text { Rate } \\
\left(\mathrm{m} \mathrm{Ma}^{-1}\right)\end{array}$ \\
\hline Carboniferous strata below Limestone Coal Formation & 355 & 327 & 28 & 3000 & 107.14 \\
\hline Limestone Coal - Passage Fm & 327 & 316 & 11 & 2000 & 181.82 \\
\hline Lower - Middle Coal Measures & 316 & 314 & 2 & 900 & 450.00 \\
\hline Middle - Upper Coal Measures & 314 & 311 & 3 & 1900 & 633.33 \\
\hline
\end{tabular}


Table 5: Estimated geothermal gradient at $60 \mathrm{Ma}$

\begin{tabular}{|l|c|r|r|r|}
\hline Easting & Northing & $\begin{array}{r}\text { Total thickness } \\
(\mathrm{m})\end{array}$ & $\begin{array}{r}\text { Basal temperature } \\
\left({ }^{\circ} \mathrm{C}\right)\end{array}$ & $\begin{array}{r}\text { Geothermal gradient } \\
\left({ }^{\circ} \mathrm{C} / \mathrm{km}\right)\end{array}$ \\
\hline 335750 & 692350 & 6049 & 146.4 & 24.2 \\
\hline 334950 & 690750 & 5990 & 145.5 & 24.3 \\
\hline 338550 & 690850 & 5532 & 139.5 & 25.2 \\
\hline 335050 & 688750 & 5647 & 140.6 & 24.9 \\
\hline 336050 & 690750 & 5888 & 144.1 & 24.5 \\
\hline
\end{tabular}


Table 6: Comparison of burial and thermal modelling results from BasinMod and HotPot. Values in square brackets are the coordinates of the nearest HotPot grid cell to the position of the borehole.

\begin{tabular}{|l|c|c|c|c|c|c|}
\hline Borehole & $\begin{array}{c}\text { Easting } \\
\mathbf{( B N G )}\end{array}$ & $\begin{array}{c}\text { Northing } \\
\mathbf{( B N G )}\end{array}$ & $\begin{array}{c}\text { HotPot total } \\
\text { thickness } \\
\mathbf{( m )}\end{array}$ & $\begin{array}{c}\text { BasinMod } \\
\text { depth of } \\
\text { burial }(\mathbf{m})\end{array}$ & $\begin{array}{c}\text { HotPot } \\
\text { basal temp. } \\
\left({ }^{\circ} \mathbf{C}\right)\end{array}$ & $\begin{array}{c}\text { BasinMod } \\
\text { max. temp. } \\
\left({ }^{\circ} \mathbf{C}\right)\end{array}$ \\
\hline Eskmouth & 334530 & 673320 & $\begin{array}{c}\text { Outside HotPot } \\
\text { model area }\end{array}$ & 2900 & $\begin{array}{c}\text { Outside } \\
\text { HotPot model } \\
\text { area }\end{array}$ & 115 \\
\hline Tower 1 & $\begin{array}{c}330024 \\
{[330050]}\end{array}$ & $\begin{array}{c}687894 \\
{[687850]}\end{array}$ & 2498 & 2900 & 89.4 & 110 \\
\hline $\begin{array}{l}\text { Milton of } \\
\text { Balgonie 1 }\end{array}$ & $\begin{array}{c}331733 \\
{[331750]}\end{array}$ & $\begin{array}{c}699335 \\
{[699350]}\end{array}$ & 2567 & 2300 & 90.7 & 95 \\
\hline
\end{tabular}

